\title{
Propriedades Temporais do Futuro Simples em Português Europeu
}

\section{Some temporal properties of the Simple Future in European Portuguese}

\author{
Luís Filipe Cunha \\ Faculdade de Letras da Universidade do Porto / Centro de Linguistica da Universidade do Porto (Portugal) \\ lisflipeleitecunha@gmail.com \\ https://orcid.org/0000-0002-1748-1053l
}

Recibido o 16/12/2019

Aceptado o 22/09/2020

\section{Resumo}

O objetivo central do presente trabalho é o de discutir algumas das propriedades temporais que caracterizam o Futuro Simples em Português Europeu. Começaremos por demonstrar que, embora este tempo gramatical veicule frequentemente informação de cariz modal, existem inúmeros contextos em que a sua função é claramente a de localizar uma situação num intervalo futuro. Nesse sentido, discutiremos algumas propostas de análise para o Futuro Simples que nos permitam dar conta das suas propriedades temporais. Assumiremos que o referido tempo gramatical exprime tipicamente uma relaçáo de posterioridade no que diz respeito ao momento da enunciação. Uma tal abordagem permite-nos dar conta não apenas dos casos de mera localização das eventualidades no eixo temporal, mas também das restriçóes aspetuais a que a designada leitura conjetural do Futuro Simples está sujeita. Finalmente, estabeleceremos uma comparação sistemática entre as propriedades temporais do Futuro Simples e da construçáo ir (no Presente do Indicativo) + Infinitivo, sustentando a ideia de que esta última apresenta restriçóes adicionais a nível temporal - em particular, a imposição de uma fronteira posterior a $t 0$ para além da qual as situaçóes não se poderiam estender -, o que explicaria a total impossibilidade da sua comparência em configuraçóes de sobreposição ao momento da enunciação, mesmo quando estão em causa predicaçóes estativas.

\section{Palavras-chave}

Semântica; tempo; aspeto, modalidade; posterioridade; futuro simples

\section{Sumario}

1 Introdução. 2 O Futuro Simples e a expressão da prospetividade. 3 Para uma análise das propriedades temporais do Futuro Simples em Português Europeu. 4 Propriedades temporais do Futuro Simples e da construção ir + Infinitivo: semelhanças e diferenças. 5 Conclusão.

\section{Abstract}

The main goal of this paper is to discuss some of the most relevant temporal properties that characterise the Futuro Simples (Simple Future) in European Portuguese. We will begin by demonstrating that, although this tense most frequently conveys modal information, it occurs in contexts in which its role is undoubtedly to locate a situation in a future time interval. In this respect, we will compare some alternative analyses in order to provide an adequate description of the temporal properties displayed by the Futuro Simples (Simple Future). We will assume that this tense conveys a systematic relation of posteriority regarding the speech time. Our assumption not only correctly accounts for the locating properties of the Futuro Simples (Simple Future) concerning the ordering of situations on the time axis, but also accommodates the aspectual restrictions shown by the so-called conjectural readings of the future tense. Finally, we will compare the temporal behaviour of the Futuro Simples (Simple Future) with that of the structure ir ('go') in the present tense + Infinitive, hypothesising that the latter construction imposes additional temporal restrictions - in particular, the presence of a boundary after $t 0$ beyond which the situations could not extend - that prevent its overlapping with the speech time, even if stative predications are involved.

\section{Keywords}

Semantics; tense; aspect; modality; posteriority; future tense

\section{Contents}

1 Introduction. 2 The Simple Future and the expression of posteriority. 3 Analysing the temporal properties of the Simple Future in European Portuguese. 4 The temporal properties of the Simple Future and of the ir ('go') + Infinitive construction: similarities and differences. 5. Conclusion. 


\section{Introdução}

$\mathrm{E}$ MBora seja inegável que o Futuro Simples do Indicativo, no Português, veicula informação de natureza eminentemente modal (vejam-se, a este respeito, observaçóes como as efetuadas por Oliveira (1986) para o Português Europeu ou por Silva (1997) para o Português do Brasil), náo deixa, contudo, de ser igualmente verdade que esta forma manifesta propriedades temporais bastante evidentes. Nesse sentido, o objetivo central do presente trabalho será o de investigar qual a caracterização semântica mais adequada para dar conta das relaçóes temporais expressas pelo Futuro Simples em contraste com o que se passa com a estrutura ir + Infinitivo, que, conquanto remeta igualmente para a prospetividade, exibe um comportamento linguístico um pouco diferente.

Se é certo que, em alguns casos, como no designado futuro de incerteza ou de conjetura (cf. Martin 1981; Dendale 2001; Laca 2016), o Futuro Simples parece manifestar um valor puramente modal, na medida em que a situação com que comparece é encarada apenas como uma possibilidade a ter lugar no momento da enunciação, sem que se observe qualquer referência a uma localização num intervalo posterior (cf. 1), outros contextos existem em que a função primordial da referida forma linguística parece ser a de situar uma eventualidade num intervalo de tempo futuro (cf. 2):

(1) Antes de feitas todas as contas, o vice-presidente Fernando Gomes garantiu que o FC Porto terá agora mais de 112.500 sócios, a que corresponde um encaixe directo de mais de 60 mil contos (cada novo associado pagou três meses de quotas). (CetemPúblico, par=ext77150-des-95a-1)

(2) Moderado por Mário Melo Rocha, o ciclo terá a sua primeira sessão, no próximo dia 3 de Fevereiro, às 21h. (CetemPúblico, par=ext265798-soc-95a-1)

Importa, por conseguinte, compreender, por um lado, qual a relação entre fatores temporais e modais que subjaz à significação do Futuro Simples e, por outro, estabelecer uma caracterização semântica adequada que dê conta das diferentes possibilidades, em termos de localização temporal, manifestadas por esta forma verbal.

Com vista a alcançar um conhecimento mais aprofundado e abrangente das propriedades temporais inerentes ao significado do Futuro Simples em Português Europeu

1. No presente artigo, sempre que possível, recorremos ao Corpus CetemPúblico, disponível online na página www.lingauteca.pt. Trata-se de um corpus do Português Europeu contemporâneo que recolhe exemplos do jornal diário Público. Informaçôes mais detalhadas sobre a sua constituição, bem como sobre a notação utilizada nos exemplos, podem ser encontradas na página referida. Em alguns casos, sobretudo quando se tornou necessário proceder a manipulação de frases, os exemplos foram criados e/ou adaptados por nós, na medida em que isso tornou possível isolar as variáveis alvo da nossa investigaçáo. 
(PE), começaremos por demonstrar, na Secção 2, que não é difícil encontrar contextos que apontam para a necessidade de uma descrição essencialmente temporal para esta forma verbal e em relação aos quais uma caracterização de cariz exclusivamente modal parece ser manifestamente insuficiente. Em seguida, colocaremos em confronto várias alternativas de análise para o comportamento linguístico do Futuro Simples, em particular a consideraçáo de esta ser uma forma ambígua, podendo expressar quer tempo, quer modo; a hipótese de o Futuro Simples veicular informação temporal de não passado, ou, ainda, na esteira de trabalhos como os desenvolvidos por Gennari (2000; 2002), a ideia de que as suas possibilidades combinatórias derivam de uma interaçáo dinâmica e complexa entre propriedades temporais, aspetuais e modais. Finalmente, na Secção 4, procuraremos dar resposta à questão das diferenças observadas entre o Futuro Simples e a construção ir + Infinitivo: embora ambas as estruturas apontem para a prospetividade, manifestam, como veremos, restriçóes de ocorrência algo distintas, o que sugere que, de facto, requerem um tratamento semântico diferenciado.

\section{O Futuro Simples e a expressão da prospetividade}

Tal como tem sido profusamente observado na literatura (cf., e.g. Oliveira 1986; Silva 1997; Mari 2009; Giannakidou \& Mari 2018; entre muitos outros), o Futuro Simples revela-se uma forma particularmente apta para a expressão de valores de cariz modal. ${ }^{2}$

Assim, por exemplo, Oliveira (1986) sublinha que o Futuro Simples remete muitas vezes para a expressão de uma eventualidade cuja realização está, até certo ponto, dependente ou condicionada pela satisfação prévia de determinados pré-requisitos. Nesse sentido, a autora postula que, em contextos deste género, a ocorrência do Futuro Simples se encontra associada à presença de uma oraçáo condicional implícita. Observe-se o seguinte exemplo ilustrativo:

(3) Numa segunda fase, a Warner-Lusomundo construirá outros «multiplex» em Barcelona, Valência, Sevilha e Saragoza. (CetemPúblico, par=ext17510-eco$-92 b-1)$

2. Sublinhe-se que as eventualidades perspetivadas num tempo futuro, ao contrário do que sucede com o presente ou com o passado, pelo simples facto de não terem ocorrido ainda no momento de avaliaçáo, têm o seu valor de verdade não especificado, comportando um maior ou menor grau de incerteza, o que torna a expressão da futuridade muito próxima da modalidade (cf. a proposta desenvolvida por Dowty (1979) acerca de histórias possíveis e futuros ramificantes ['inertia futures']). Esta característica é comum a todas as formas que remetem para a prospetividade. No entanto, como veremos, o Futuro Simples veicula adicionalmente outros valores modais, nomeadamente epistémicos e deônticos, e é a estes que nos estamos a referir no início da presente secção. 
Tal como nos é aqui apresentada, uma frase como esta parece equivaler a uma configuração do género de "Numa segunda fase, a Warner-Lusomundo construirá outros «multiplex» em Barcelona, Valência, Sevilha e Saragoza [\{se as condiçôes de mercado se mantiverem estáveis / se se der continuidade à política de expansão internacional da empresa...\}]". Ou seja, o Futuro Simples, em determinados contextos, parece favorecer uma leitura condicionada (i.e., modalizada) da ocorrência da situação que perspetiva, o que se traduz na necessidade de considerar uma oração condicional implícita, essencial para a compreensão global do enunciado.

Existem ainda outros casos em que os valores modais associados ao Futuro Simples se manifestam de forma bastante evidente. É o que sucede com as frases que se apresentam em (4-6), em que o Futuro Simples, muito embora veiculando, de modo inequívoco, uma relação de posterioridade, parece equivaler a um modal epistémico:

(4) Por outro lado, o Partido Popular, que se opóe veementemente a laços mais estreitos com a Europa, ganhará (= pode / deve ganhar) mais um deputado, ficando com 26, segundo esta projecçáo inicial. (CetemPúblico, par=ext4242-pol-91b-1)

(5) A taxa de inflação em Espanha alcançará (= deve alcançar) 2,5 por cento em 1998, de acordo com as previsóes do jornal económico «Expansion», com base em estimativa de analistas. (CetemPúblico, par=ext57832-eco-97b-2)

(6) $\mathrm{Na}$ avaliação efectuada por alguns responsáveis e especialistas, o número de desempregados alcançará (= pode alcançar) os 15 milhōes de russos ainda este ano caso se concretize o programa governamental das falências. (CetemPúblico, par=ext840137-nd-94b-1)

Embora se verifique alguma variação relativamente ao grau de certeza associado ao uso do Futuro Simples em frases como estas - o que pode ser atestado pela oscilação entre a escolha dos verbos poder e dever nas respetivas paráfrases -, o certo é que, em qualquer dos casos, nos encontramos face à expressão de modalidade epistémica, na medida em que não é plenamente assumida a veracidade das proposiçóes envolvidas, subsistindo, em maior ou menor grau, dúvida ou incerteza quanto à sua concretização no mundo de referência. ${ }^{3}$ Nesse sentido, o Futuro Simples pode receber um significado equivalente ao de verbos modais como poder ou dever. ${ }^{4}$

3. Para uma apresentaçáo detalhada dos diferentes tipos de modalidade, vejam-se, por exemplo, Palmer (1986) ou Portner (2009).

4. Embora muito menos frequentes em PE, quando comparados com as construçóes que exprimem modalidade epistémica, é possível encontrar casos em que o Futuro Simples remete para a modalidade deôntica, como ilustrado em (i):

(i) O mandamento da avó de Russell não podia ser mais claro: não seguirás (= deves seguir) uma multidão para fazer o mal. (CetemPúblico, par=ext769053-nd-93b-2) 
Os designados usos conjeturais ou de incerteza ${ }^{5}$, em que o Futuro Simples não projeta uma situaçáo num intervalo ulterior a $t 0^{6}$, mas a apresenta como uma hipótese ou como uma possibilidade que carece de confirmação em relação ao tempo da enunciação (cf. 7-8), comprovam que esta forma verbal está indissociavelmente ligada à expressão de propriedades de natureza essencialmente modal.

(7) $\mathrm{O}$ «pequeno timoneiro», 91 anos em Agosto, se lá chegar, já não é visto em público desde Fevereiro de 1994 e estará gravemente doente. (CetemPúblico, par=ext1179544-pol-95a-2)

(8) O Público apurou que Konis Santana terá cerca de trinta anos e é natural de Lautém Los Palos, na ponta leste de Timor, onde o seu pai desempenhava funçôes na administração local. (CetemPúblico, par=ext169831-pol-93b-1)

Em frases como (7) e (8) o Futuro Simples não impóe uma relação temporal de posterioridade às situaçóes com que se combina, na medida em que as hipóteses ou conjeturas formuladas são tipicamente cotemporais com o momento da enunciação; a sua principal função parece, pois, ser a de conferir um carácter de dúvida ou de incerteza às proposiçóes a que se aplica.

Nessa medida, frases como estas podem ser facilmente parafraseáveis por formas do Presente do Indicativo associadas a um adverbial do domínio da incerteza, do género de provavelmente ou de possivelmente, como os exemplos que se seguem nos confirmam:

(9) $\mathrm{O}$ «pequeno timoneiro», 91 anos em Agosto, se lá chegar, já não é visto em público desde Fevereiro de 1994 e possivelmente está gravemente doente.

(10) O Público apurou que Konis Santana tem, provavelmente, cerca de trinta anos e é natural de Lautém Los Palos, na ponta leste de Timor, onde o seu pai desempenhava funçôes na administração local.

As propriedades semânticas manifestadas pelo Futuro Simples que até aqui observámos - nomeadamente (i) a tendência para se associar a uma oração condicional implícita em determinado tipo de contextos, (ii) a capacidade de exprimir valores ine-

Os contextos em que o Futuro Simples veicula valores modais - epistémicos ou deônticos - parecem estar sujeitos a uma variação bastante significativa de acordo com as diversas línguas selecionadas (para uma apresentação comparativa de dados relativos ao Francês, ao Italiano e ao Espanhol, veja-se Stage 2002).

5. Para uma discussão mais aprofundada deste género de interpretaçóes associadas ao Futuro Simples, vejam-se, entre muitos outros, Martin (1981), Dendale (2001) ou Laca (2016).

6. Assumimos aqui que $t 0$ designa o intervalo básico ou "original" a partir do qual se irão estabelecer as restantes relaçóes temporais, i.e., o momento da enunciação. 
quivocamente modais, em particular no que toca à modalidade epistémica, revelando a possibilidade de alternar com verbos como poder ou dever e (iii) a ocorrência em configuraçóes conjeturais ou hipotéticas cotemporais com o momento da enunciação - sugerem que esta forma verbal poderia ser simplesmente concebida como um operador de modalidade. ${ }^{7}$

No entanto, uma abordagem nestes termos acabará por se revelar excessivamente forte, na medida em que, como veremos, existem argumentos que nos levam a considerar que, em contextos adequados, o Futuro Simples contribui igualmente, de forma decisiva, para a localizaçáo das eventualidades com que comparece num intervalo posterior a $t 0$.

Nesse sentido, não nos será difícil encontrar sequências em que a função temporal desempenhada pelo Futuro Simples se parece sobrepor à expressão da modalidade.

Tal como referido, por exemplo, em Móia (2017), não são raros os casos em que o Futuro Simples integra proposiçóes que exprimem um alto grau de certeza. Os exemplos que se seguem ilustram este facto:

(11) Em dia de aniversário, Luís Rouxinol ofereceu a si mesmo a prenda de um triunfo redondo, que com toda a certeza figurará com destaque na colecçáo de louros da sua carreira. (CetemPúblico, par=ext1487915-soc-93b-1)

(12) De fora ficará, de certeza, Lucrécia Jardim, cuja lesão nos adutores a fará, também, estar ausente em Braga. (CetemPúblico, par=ext30357-des-97a-2)

Expressões como 'com toda a certeza', em (11), ou 'de certeza', em (12), parecem contribuir para uma interpretação em que a realização futura das eventualidades descritas nos é dada como plenamente garantida no momento da enunciaçáo.

Tendo em consideração o elevado grau de certeza associado às sequências que acabámos de apresentar, parece lícito concluir que a interpretação aqui conferida ao Futuro Simples é de natureza essencialmente temporal, sendo a sua função principal a de localizar prospetivamente as situaçôes com que coocorre. A confirmar tal observaçáo está o facto de que, ao contrário do que observámos para os exemplos anteriormente discutidos neste trabalho, o Futuro Simples não pode ser parafraseado, em frases como estas, por verbos modais do género de poder ou de dever (cf. 13-14):

(13) Em dia de aniversário, Luís Rouxinol ofereceu a si mesmo a prenda de um triunfo redondo, que com toda a certeza $\{*$ pode / ?? deve / vai\} figurar com destaque na colecçáo de louros da sua carreira.

(14) De fora $\left\{{ }^{*}\right.$ pode / ?? deve / vai\} ficar, de certeza, Lucrécia Jardim, cuja lesão nos adutores a fará, também, estar ausente em Braga.

7. Parece ser esta, de resto, a linha de análise adotada por Giannakidou \& Mari (2018) para explicar o comportamento das formas de futuro simples em Grego e Italiano. 
Um outro contexto em que uma interpretação eminentemente temporal do Futuro Simples parece ser claramente favorecida diz respeito aos casos em que os estados de coisas que ocorrem com este temo verbal são concebidos como perfeitamente previsíveis ou mesmo inevitáveis, tendo em conta o nosso conhecimento do mundo, em particular de determinadas regularidades associadas a fenómenos naturais recorrentes. É o que sucede em exemplos como (15) e (16):

(15) Com a forma semelhante a uma caveira, o pequeno asteroide 2015 TB145 gira em torno do seu eixo e passará próximo da Terra, pela segunda vez, em novembro do próximo ano. (Jornal de Noticias, 26/12/20178).

(16) Mas, quando as chuvas pararem, daqui a umas semanas, e a comida começar a escassear, o destino destes insectos já está marcado: formarão imensas nuvens vivas e migrarão para as regiões habitadas e cultivadas. (CetemPúblico, par=ext1077164-clt-soc-93b-2)

Também aqui, e por estar explicitada a expressão de um elevado grau de certeza, habitualmente pouco compatível com o recurso a verbos modais, as paráfrases em que surgem poder ou dever não se revelam inteiramente adequadas, o que indicia que o Futuro Simples remete sobretudo para a localizaçáo temporal das situaçóes envolvidas:

(17) Com a forma semelhante a uma caveira, o pequeno asteroide 2015 TB145 gira em torno do seu eixo e ${ }^{*}$ pode / ?? deve / vai\} passar próximo da Terra, pela segunda vez, em novembro do próximo ano.

(18) Mas, quando as chuvas pararem, daqui a umas semanas, e a comida começar a escassear, o destino destes insectos já está marcado: ${ }^{*}$ podem / ?? devem / vão\} formar imensas nuvens vivas e $\left\{{ }^{*}\right.$ podem / ?? devem / vão\} migrar para as regióes habitadas e cultivadas.

A plena compatibilidade do Futuro Simples com sequências em que adverbiais temporais ou outras expressóes equivalentes fornecem uma localização precisa ou exata, num intervalo futuro, para as eventualidades descritas pode igualmente ser invocada como um bom argumento em favor da ideia de que a forma verbal em questão contribui, pelo menos em certa medida, com informaçáo temporal relevante para a interpretação final das configuraçôes em que se insere. Observem-se os seguintes exemplos:

8. https://www.jn.pt/mundo/interior/asteroide-em-forma-de-caveira-passara-perto-da-terra-em-2018-9009653.html 
(19) Assim, o Quarteto Cedrón e la Típica actuará no Teatro da Trindade, em Lisboa, no dia 18 , terça-feira, às $21 \mathrm{~h} 45$, enquanto o outro grupo, El Vieju Almacén, se apresentará no mesmo local e à mesma hora nos dias 19, 20, 21, 22 e 24 , e a 23 e 25 às 16h. (CetemPúblico, par=ext164521-clt-95a-2)

(20) As provas terão início hoje às $17 \mathrm{~h} 00$ e amanhã às 16h30. (CetemPúblico, par=ext987741-des-92a-1)

(21) A partir de hoje (terça a sábado às $21 \mathrm{~h} 30$, domingos às $16 \mathrm{~h}$ ), estará sozinho no palco do Teatro da Cornucópia repondo «A Hipótese», de Robert Pinget, espectáculo estreado em 1989. (CetemPúblico, par=ext346147-clt-91b-1) ${ }^{9}$

Os diferentes adverbiais temporais representados em (19-21), ao fornecerem uma localização precisa para as eventualidades com que se combinam, parecem induzir uma interpretação preferencialmente temporal ao Futuro Simples, dando conta de uma localização num intervalo bem definido, posterior ao momento da enunciação. ${ }^{10}$

9. Embora o propósito central destes exemplos seja o de comprovar a existência de marcas inequívocas de temporalidade associadas ao Futuro Simples, não podemos deixar de concordar plenamente com a observação de um dos revisores do presente artigo que chama a atenção para o facto de que, na sua interpretaçáo final, estas frases resultam da interaçáo dinâmica entre os diferentes elementos que as constituem. Na realidade, para a leitura global destes exemplos contribuem náo apenas o tempo gramatical escolhido, mas também os diferentes adverbiais representados. Por outras palavras, o valor temporal de futuridade que caracteriza estas configuraçóes resulta, em última instância, de toda a informação veiculada pelas diversas formas que coocorrem na sequência.

10. Importa deixar bem claro que não é a mera presença deste género de adverbiais mas antes o alto grau de "precisão" ou de "exatidão" da localização por eles efetuada que contribui para a leitura temporal atribuída ao Futuro Simples, como o contraste que se segue deixa bem claro:

(i) Para combater a dívida de 120 milhōes de dólares, o partido venderá \{pode vender / deve vender / vai vender\} as suas propriedades, a começar pelo luxuoso centro de congressos Belsito, um ex-cinema no centro de Roma que simboliza o templo do craxismo. (CetemPúblico, par=ext429649-pol-93a-1)

(ii) Para combater a dívida de 120 milhóes de dólares, nos próximos anos o partido venderá \{pode vender / deve vender / vai vender\} as suas propriedades, a começar pelo luxuoso centro de congressos Belsito, um ex-cinema no centro de Roma que simboliza o templo do craxismo.

(iii) Para combater a dívida de 120 milhóes de dólares, amanhá às $17.30 \mathrm{~h}$ o partido venderá $\left\{{ }^{*}\right.$ pode vender / ? deve vender / vai vender\} as suas propriedades, a começar pelo luxuoso centro de congressos Belsito, um ex-cinema no centro de Roma que simboliza o templo do craxismo.

Tal como as paráfrases nos indicam, uma frase como (i) pode receber, sem problemas, tanto uma leitura modal quanto uma interpretaçấo temporal. Esta dupla possibilidade mantém-se inalterada quando lhe é acrescentado um adverbial de localizaçāo temporal relativamente vaga (cf. [ii]). No entanto, se o adverbial remete para uma localização mais "precisa" ou "exata", o valor temporal associado ao Futuro Simples parece prevalecer sobre o de modalidade (cf. [iii]). É nesse sentido que defendemos aqui a ideia de que a localização precisa das situaçôes favorece uma leitura temporal do Futuro Simples. 
Por isso mesmo, e tal como observámos para as restantes leituras em que o valor temporal do Futuro Simples se revela predominante, a paráfrase mais adequada para estes exemplos é a que recorre à construção ir + Infinitivo, mostrando-se os verbos modais poder e dever menos apropriados neste tipo de contextos:

(22) Assim, o Quarteto Cedrón e la Típica $\left\{{ }^{*}\right.$ pode /? deve / vai\} actuar no Teatro da Trindade, em Lisboa, no dia 18, terça-feira, às $21 \mathrm{~h} 45$, enquanto o outro grupo, El Vieju Almacén, se \{* pode / ? deve / vai\} apresentar no mesmo local e à mesma hora nos dias 19, 20, 21, 22 e 24, e a 23 e 25 às 16 h.

(23) As provas $\{*$ podem / ? devem / vão\} ter início hoje às 17 h00 e amanhã às $16 \mathrm{~h} 30$.

(24) A partir de hoje (terça a sábado às $21 \mathrm{~h} 30$, domingos às $16 \mathrm{~h}$ ), \{* pode / ?? deve / vai\} estar sozinho no palco do Teatro da Cornucópia repondo «A Hipótese», de Robert Pinget, espectáculo estreado em 1989.

Em suma, contextos como aqueles em que (i) se encontra explicitamente expresso um alto grau de certeza quanto à realização futura de uma dada situação, (ii) o nosso conhecimento do mundo e de determinados fenómenos naturais nos leva a assumir, sem margem para dúvidas, a necessidade ou a inevitabilidade da ocorrência futura de certas eventualidades e (iii) a localização precisa promovida por adverbiais temporais num intervalo prospetivo contribui para a consideração da efetiva concretização da situação em apreço indiciam fortemente que o Futuro Simples, para além dos valores modais que transmite, veicula igualmente informação de natureza inequivocamente temporal.

Importa, pois, tentar compreender como é que tal informação temporal se encontra codificada na semântica do tempo gramatical sob análise. É a esta questáo que iremos dedicar a próxima secção do presente trabalho.

\section{Para uma análise das propriedades temporais do Futuro Simples em PE}

Tomando como ponto de partida os dados observados na secção anterior, importa refletir agora sobre algumas das propriedades semânticas que caracterizam o Futuro Simples em Português Europeu.

Em primeiro lugar, e dadas as evidências da presença de marcas explícitas de temporalidade associadas a esta forma verbal, diríamos que são de excluir, à partida, tratamentos exclusivamente baseados nas propriedades modais exibidas pelo Futuro Simples. Parece ser o caso, por exemplo, de propostas como as de Alarcos Llorach (1972; 1994), que, para o Espanhol, sugere a existência de um quarto modo - para 
além do Indicativo, do Conjuntivo e do Imperativo - que podemos designar como Modo Condicionado ou Potencial e em que inclui as formas do futuro e do condicional. Como ponto de partida para justificar esta opção, o autor observa que tanto o Futuro quanto o Condicional remetem para o domínio do não realizado (logo, da modalidade), sem, contudo, tomar em consideração as diferenças, em termos de grau de certeza, que se podem observar entre as proposiçóes que acabámos de discutir na secção anterior. $\mathrm{Na}$ realidade, a não realização de determinadas situaçôes perspetivadas no Futuro Simples prende-se mais com o facto de tomarmos o momento de enunciação como centro dêitico de avaliação do que propriamente com o caráter modal das formas de futuro, nomeadamente nos casos em que o seu significado temporal é preponderante. ${ }^{11}$ Por esta mesma razão, não adotaremos aqui igualmente análises, como aquelas que nos são oferecidas por Giannakidou \& Mari $(2013$; 2018) para estruturas equivalentes no Grego e no Italiano, que sugerem que o valor semântico central do Futuro Simples é o de um modal epistémico.

Se é certo que o Futuro Simples, ao projetar as eventualidades com que se combina em intervalos de tempo posteriores ao momento da enunciação, torna inviável a atribuição de um valor de verdade às predicaçóes com que coocorre, remetendo, nesse sentido, para o domínio do não realizado ou do possível, i.e., da modalidade ${ }^{12}$, não deixa, contudo, de ser inegável que, como vimos, persiste uma distinção muito clara entre usos eminentemente modais, sobretudo de cariz epistémico - de que se destaca o designado valor hipotético ou conjetural -, e usos essencialmente temporais, em que é a localização da situação num intervalo posterior a $t 0$ que parece estar em causa.

Abordagens que apenas tenham em consideraçáo a componente modal associada ao Futuro Simples colocam-nos, por conseguinte, alguns problemas de difícil resolução.

Nesse sentido, se assumirmos que o Futuro Simples transmite exclusivamente informação de natureza modal, teremos grandes dificuldades em explicar a distinção entre os usos claramente modais associados a esta forma verbal, em que a paráfrase por verbos do género de poder ou de dever se constitui como a opção preferencial, e enunciados em que a componente temporal parece ser preponderante, e em que a substituição pelos verbos modais se revela quase sempre inadequada (cf. a discussão levada a cabo na secção anterior).

11. Agradeço a um revisor/a deste trabalho a chamada de atençáo para a pertinência das propostas de Alarcos Llorach (1961; 1972; 1994) a este respeito.

12. Levada ao extremo, esta linha de pensamento prediz que todos os futuros são, de uma maneira ou de outra, de natureza modal, o que estaria na base do desenvolvimento de propostas como as que conduzem à formulação das noçôes de histórias possíveis e de futuros ramificantes (cf. Dowty 1979). Embora, em termos teóricos, esta conceção nos pareça correta, importa, face à diversidade de comportamentos linguísticos e de interpretaçóes manifestada pelo Futuro Simples, manter a distinção entre leituras essencialmente modais e leituras eminentemente temporais, mesmo estando cientes de que a própria noção de localização futura implica, de alguma forma, a de modalidade. 
Por outro lado, uma análise estritamente modal não será capaz, por si só, de dar conta de certas restriçóes que se observam relativamente aos designados usos hipotéticos ou conjeturais do Futuro Simples.

Como já referimos anteriormente, o Futuro Simples pode comparecer em predicaçóes que exprimem hipóteses ou possibilidades avaliadas em relação ao momento da enunciação e não a um intervalo prospetivo, como ilustrado em (25) e (26):

(25) Assim, a maior parte dos trabalhadores despedidos nessa altura viverá agora com «mais problemas", e a doença, a insegurança e a solidão são as situaçóes mais evidenciadas. (CetemPúblico, par=ext399485-nd-91b-2)

(26) Antes de feitas todas as contas, o vice-presidente Fernando Gomes garantiu que o FC Porto terá agora mais de 112.500 sócios, a que corresponde um encaixe directo de mais de 60 mil contos (cada novo associado pagou três meses de quotas). (CetemPúblico, par=ext77150-des-95a-1)

A uma primeira vista, dados como estes parecem justificar plenamente a adoção de um tratamento puramente modal para o Futuro Simples, tendo em conta que, em frases como (25) e (26), apenas são expressas hipóteses e conjeturas relativas ao momento da enunciação, não havendo qualquer indício de localização futura das situaçôes envolvidas.

No entanto, este tipo de interpretação parece estar limitado por fatores aspetuais, na medida em que apenas predicaçóes de natureza claramente estativa parecem satisfazer as condiçóes para o receber, sendo uma leitura de cariz puramente conjetural praticamente impossível com eventos, como o contraste que se segue nos comprova: ${ }^{13}$

(27) O João terá agora $^{14}$ uns cinquenta anos. (estado)

(28) A Maria viverá agora em Paris. (estado)

(29) * O João fará agora festas ao seu gato. (processo)

(30) * A Maria comerá agora a sopa. (processo culminado)

(31) * O Pedro ligará agora o rádio. (culminação) $)^{15}$

13. Observaçóes semelhantes podem ser encontradas em Gennari (2000; 2002) ou em Rocci (2000), entre outros.

14. Excluímos aqui, naturalmente, o significado de 'agora' correspondente a 'dentro de momentos', já que este licencia uma projeção futura das situaçóes envolvidas, perfeitamente compatível com qualquer classe aspetual de predicaçóes.

15. Seguimos, no presente trabalho, a classificação aspetual proposta por Moens (1987); vejam-se, igualmente, Vendler (1967) e Binnick (1991) para os critérios de caracterização das diferentes classes aspetuais de predicaçóes. 
Um tratamento puramente modal para o Futuro Simples afigura-se, em nosso entender, incapaz de resolver satisfatoriamente o problema colocado por exemplos como (27-31): por que razão apenas estativos, e não eventos, podem receber uma interpretação hipotética ou conjetural, em que a ocorrência das predicaçóes é avaliada em relação ao momento da enunciação e a um mundo possível diferente de $w 0$, o mundo de referência? O que impede os eventos de manifestarem uma leitura de índole modal semelhante a esta? Retomaremos a questáo em breve, aquando da apresentação e discussão das propostas de Gennari (2000; 2002).

Uma outra estratégia para descrever o comportamento linguístico manifestado pelo Futuro Simples pode passar por considerar esta forma como sendo ambígua entre um operador temporal e um operador de modalidade. É esta a opçáo tomada por autores como Condoravdi (2003), Mari (2009), Falaus \& Laca (2014) ou Laca (2016) e, especificamente para o Português, por Cunha \& Cintra (1984) ou Giomi (2010). Neste género de análise, a seleção de cada um dos significados associados ao Futuro Simples estaria, em certa medida, dependente de condiçóes semânticas, pragmáticas e contextuais que, em cada caso concreto, permitiriam desambiguar as ocorrências em questão.

Assim, por exemplo, poderia ser postulado o princípio de que, quando estão envolvidos estados, o Futuro Simples funcionaria como um operador modal, ao passo que, sempre que surgem predicaçóes eventivas, ele manifestaria o comportamento de um operador essencialmente temporal, o que nos permitiria dar conta das assimetrias observadas nos exemplos de (27)-(31).

No entanto, a adoção de uma abordagem deste género não está isenta de problemas de difícil resolução.

Se o Futuro Simples é considerado uma forma ambígua, capaz de dar origem a interpretaçôes ou de natureza exclusivamente modal, ou de cariz unicamente temporal, não seria de esperar que fossem encontradas ocorrências em que estas duas leituras coexistissem de forma bastante evidente. Contudo, exemplos como (32) e (33) parecem contrariar uma tal predição:

(32) Por outro lado, o Partido Popular, que se opõe veementemente a laços mais estreitos com a Europa, ganhará (= pode ganhar) mais um deputado, ficando com 26, segundo esta projecção inicial. (CetemPúblico, par=ext4242-pol$-91 b-1)$

(33) São 19 horas em Newcastle (Inglaterra) e o navio vai zarpar dentro de poucos minutos, rumo a Bergen, na Noruega, onde só chegará (= deve chegar) na tarde do dia seguinte. (CetemPúblico, par=ext17258-soc-95b-1)

Em frases como estas, observamos que o Futuro Simples veicula informação de cariz claramente modal - no caso, de modalidade epistémica -, o que se torna bem patente pela possibilidade de o substituir por verbos modais do género de poder ou 
de dever. No entanto, e ao contrário do que sucede com os designados usos puramente conjeturais, as predicaçóes envolvidas são inequivocamente projetadas para um intervalo de tempo futuro (cf. a referência a "esta projeção inicial" em [32] ou a presença explícita de um adverbial que remete para a posterioridade - "na tarde do dia seguinte" - em [33]).

Podemos, entâo, considerar que, pelo menos em casos como os representados em (32) e (33), não será fácil fornecer uma explicação simplesmente baseada no conceito de ambiguidade entre leituras temporais e interpretaçóes modais, na medida em que nos encontramos face à combinação harmoniosa destas duas propriedades semânticas numa mesma configuração, circunstância pouco compatível com a ideia de escolha entre dois significados autónomos que a noção de ambiguidade parece acarretar.

Por outro lado, considerar o Futuro Simples como sendo ambíguo entre leituras temporais e modais dificultaria a adoção de um tratamento unificado para esta forma verbal, tratamento esse que, em nossa opinião, se constitui como a estratégia mais adequada para dar conta dos diversos factos que temos vindo a observar. ${ }^{16}$

16. Opinião semelhante é defendida em Escandell-Vidal (2010; 2014), que, embora proponha uma análise bastante diferente daquela que aqui iremos apresentar, argumenta convincentemente em favor de um tratamento unificado para a caracterizaçáo semântica do Futuro Simples em Espanhol. Segundo a autora, esta forma verbal constituir-se-ia como uma manifestaçáo da categoria gramatical de evidencialidade. Em particular, indicaria que o conteúdo proposicional sob o seu escopo teria como única fonte de informação o enunciador e que o tipo de evidência que exprime seria a "inferência intuitiva". Uma abordagem nestes termos não nos parece, todavia, aplicar-se aos dados do Português Europeu aqui analisados, na medida em que (a) ao contrário do que é referido para o espanhol (cf. Escandell-Vidal 2014: 10.6.1), o enunciador não é necessariamente a única fonte de informação disponível para o conteúdo proposicional em estruturas envolvendo o Futuro Simples, sendo fácil encontrar casos de situaçóes "planeadas" ou "decididas" por terceiros (ex.: a organizaçẫo do campeonato do mundo de futebol em [i]); (b) no Português Europeu, existem abundantes casos em que o Futuro Simples exprime evidência "reportiva", i.e., em que a informaçáo veiculada é explicitamente atribuída a uma fonte externa ao enunciador, o que contraria não só a hipótese de que o enunciador é a única fonte de informaçáo disponível mas também o facto de o Futuro Simples veicular sempre uma inferência intuitiva (cf. [ii]); (c) os casos em que o Futuro Simples é compatível com um alto grau de certeza - principalmente aqueles em que surgem expressóes que promovem a localizaçáo precisa das predicaçôes num intervalo prospetivo - não parecem ser fáceis de compatibilizar com a ideia de "inferência intuitiva" (cf. [iii]), na medida em que remetem preferencialmente para situaçôes concretas encaradas na sua factualidade e projetadas no futuro; (d) finalmente, uma abordagem deste género deixa por explicar as divergências, em termos de restriçôes aspetuais e de comportamento linguístico, manifestadas por estados e eventos com o Futuro Simples que temos vindo a apontar ao longo deste trabalho.

(i) O Brasil, campeão mundial, abrirá a competição a 10 de Junho, frente à selecção da Escócia, e jogará depois com Marrocos e Noruega. (CetemPúblico, par=ext13075-nd-97b-1)

(ii) Segundo as empresas Harris e Belden e o jornal «Reforma», por exemplo, Zedillo vencerá com 43, 46 e 46 por cento, respetivamente. (CetemPúblico, par=ext453240-pol-94b-1) 
No sentido de contornar os problemas que a noção de ambiguidade nos coloca, poderemos considerar a hipótese de tratamento para o Futuro Simples do Espanhol que nos é oferecida por Rojo \& Veiga (1999). Com base numa longa tradição gramatical, que remonta à Gramática Castellana de Andrés Bello de 1847, e que conhece continuidade em trabalhos como os de Bull (1960) e de Rojo (1974), os autores propóem que o Futuro Simples veicula um significado essencialmente temporal de posterioridade, que designam como o seu uso 'reto' ('significado fundamental', na terminologia de Bello ou 'systemic function', na de Bull). Como resultado do fenómeno a que dão o nome de 'deslocação do sistema temporal' - que não se cinge, naturalmente, ao caso que aqui nos ocupa, mas que permite explicar também outras alternâncias relacionadas no interior do sistema verbal espanhol ${ }^{17}$ -, em circunstâncias adequadas o Futuro Simples pode passar a expressar um valor marcado, neste caso de modalidade, que designam como uso 'deslocado'. Nesse processo de deslocaçáo de sentido, o Futuro Simples (i) perde o seu valor temporal de posterioridade, passando a comportar-se como um presente i.e., localizando a situação com que se combina num intervalo que inclui o momento da enunciação e (ii) adquire um valor modal de epistemicidade. ${ }^{18}$ Em certa medida, este fenómeno seria equivalente, no plano da temporalidade, à noção de derivação aspetual - que permite a conversão de uma classe básica numa categoria de tipo derivado - explorada por autores como Moens (1987), Binnick (1991) ou de Swart (1998) no domínio do Aspeto.

Uma análise deste género permite, por um lado, colocar em evidência o papel central que a informação temporal ocupa na caracterização semântica do Futuro Simples e, por outro, explicar facilmente os casos que aqui designei como de leituras conjeturais ou hipotéticas (cf. "O João terá agora trinta anos"; ver também a discussão dos exemplos [25] e [26]), mas coloca problemas aos exemplos que combinam uma interpretação de posterioridade com um valor claramente epistémico (cf. "Amanhã a equipa vencerá o jogo" na interpretação equivalente a "Amanhã a equipa pode/ deve vencer o jogo", "É possível que amanhã a equipa vença o jogo"; veja-se também a discussão de exemplos como [32] e [33]). Dado que Rojo e Veiga (1999) fazem depender a emergência de um valor 'deslocado' (i.e., de uma interpretação modal de conjetura) da perda das propriedades temporais básicas do Futuro Simples, a propos-

(iii) Finalmente, às 22h30, a jovem pianista Luísa Tender tocará peças de Beethoven, Brahms e Chopin na Galeria Mário Sequeira, em Tibães, Braga. (CetemPúblico, par=ext1562445-soc$-98 a-1)$

17. Este fenómeno de "deslocação do sistema temporal" seria igualmente responsável e permitiria, por exemplo, explicar as leituras de "irrealidade" muitas vezes associadas às formas de Condicional, que deixariam de veicular a localizaçáo de uma situação no futuro do passado para a reconverter numa proposição contrafactual no presente (cf. "Se eu fosse rico, estaria neste momento nas Caraíbas").

18. Agradeço a um revisor/a da revista o facto de me ter chamado a atenção para a relevância destas propostas de análise para o meu trabalho. 
ta não prevê a combinação de valores temporais e modais numa mesma predicação, ao contrário do que os factos nos revelam.

Tomemos, a título de exemplo, uma frase como "No próximo ano, a cidade do Porto estará mais poluída", com o seu significado preferencial de "No próximo ano, a cidade do Porto deve estar mais poluída" ou "No próximo ano, é possível que a cidade do Porto esteja mais poluída”. Se considerarmos, a partir da informação temporal disponibilizada, que nos encontramos perante um uso 'reto' do futuro, teremos de aceitar que a sua interpretação modal é, em certa medida, independentemente alcançada, o que torna necessária uma explicação adicional para a distinção entre estes usos de futuro modalizado ou epistémico e aqueles que podemos designar como de futuro temporal 'puro' (cf. e.g. “A nova loja abrirá amanhã às $15 \mathrm{~h}$ ”). Se, por outro lado, admitirmos que se trata de um uso 'deslocado', devido à proeminência da interpretação modal, teremos que explicar por que razão em certos casos a localização das situaçóes é efetuada num intervalo posterior ao momento da enunciação e noutros se observa uma relação de sobreposição. Em suma, dado que as interpretaçôes temporais e epistémicas atribuídas ao Futuro Simples não se encontram em distribuição complementar, a distinção entre usos 'retos' e 'desviados' atribuída a este tempo gramatical só parcialmente descreve o seu comportamento linguístico.

Por outro lado, importa não esquecer que as restriçôes aspetuais associadas às leituras de sobreposição do futuro ao momento da enunciação que observámos atrás - em particular a assimetria de comportamento manifestada por estados e eventos também não são referidas nem parecem poder receber uma explicação adequada na proposta de Rojo \& Veiga (1999).

Tomando em linha de conta toda a discussão que levámos a cabo até ao momento, parece ter ficado claro que, para além dos diferentes valores modais que possa exprimir (cuja análise, por razóes de espaço, teremos de deixar para um próximo trabalho), e independentemente das condiçóes que lhes estão subjacentes, o Futuro Simples está seguramente associado a informaçáo de cariz temporal. Importa, portanto, tentar caracterizar as propriedades temporais manifestadas por esta forma verbal com base nas relaçôes de localização em que se encontra envolvida.

Dado que o Futuro Simples pode comparecer tanto com situaçóes que seguem o momento da enunciação quanto com eventualidades que se lhe sobrepóem, uma primeira hipótese a considerar seria a de que esta forma se encontraria associada à expressão de um intervalo não passado.

Existem, contudo, alguns argumentos que póem em causa esta linha de análise.

Em primeiro lugar, na ausência de adverbiais temporais ou de outros elementos, contextuais ou linguísticos, que favoreçam uma leitura de sobreposição, o Futuro Simples parece remeter consistentemente para a localização, num intervalo futuro, das situaçóes com que coocorre, sejam eventos (cf. 34-35), sejam estativos (cf. 36): 
(34) Para ela, André Alvarenga desenhará 20 peças para os tecidos artesanais de Elsa e outras 20 de produção industrial, que irão conviver no corpo dos modelos, "pelo gosto de conciliar o conflito». (CetemPúblico, par=ext565448-clt-92a-1)

(35) Neste período de tempo, não só se construirá o famoso tecto como também se aproveitará para reformar o edifício que, entre outros males, sofre de amianto - uma substância altamente tóxica, provocadora do cancro, muito usada, em tempos, na construção civil. (CetemPúblico, par=ext183997-cl$\mathrm{t}-91 \mathrm{a}-2)$

(36) A fábrica terá uma área de nove mil metros quadrados, por onde se repartirão a linha de produçáo, armazém e administração. (CetemPúblico, par=ext11609-eco-95b-2)

Nos exemplos acima representados, na ausência de adverbiais temporais ou de outros elementos (extra)linguísticos equivalentes que forneçam indicaçóes claras sobre a localização das eventualidades descritas no eixo temporal (cf. [34] e [36]) ou em conjugação com adverbiais que não comportam uma orientação temporal específica (cf. "neste período de tempo"19 em [35]), o Futuro Simples remete, inequivocamente, para a prospetividade, não se observando qualquer tipo de ambiguidade com respeito a uma eventual sobreposição das situaçóes ao momento da enunciação.

Por outro lado, observamos que, mesmo nos casos em que a duração das situaçóes descritas é manifestamente prolongada no tempo, a leitura preferencial do Futuro Simples continua a ser a de prospetividade, salvo se existirem indicaçóes explícitas em contrário. É o que sucede, por exemplo, com as construçôes habituais ou quantificacionais ilustradas nas frases que se seguem:

(37) No entanto, esta instituição, que terá as suas portas abertas 24 horas por dia, atenderá todos os sem-abrigo da área metropolitana que recorram aos seus serviços, sem limite de número. (CetemPúblico, par=ext9374-soc$-95 b-2)$

(38) O grupo organizará, ainda, a terceira edição do Festival de Portalegre e promoverá todos os meses na cidade um espectáculo de outra companhia. (CetemPúblico, par=ext212440-clt-93a-2)

19. Sublinhe-se que um adverbial como "neste período de tempo" é perfeitamente compatível com a localizaçáo de situaçóes no passado (cf. "Neste período de tempo construíram-se várias estradas"), no presente (cf. "Neste período de tempo estão a ser construídas várias estradas") ou no futuro (cf. "Neste período de tempo vão ser construídas várias estradas"), o que sustenta a nossa afirmação de que a expressão em apreço não se revela capaz de fornecer uma orientação temporal específica para as eventualidades com que se combina. 
Os exemplos de (37) e (38) ilustram a recorrência ou a repetição de certos eventos - "atender os sem-abrigo da área metropolitana" em (37) e "promover um espectáculo de outra companhia” em (38). Este padrão de repetição supóe que as situaçôes em apreço decorrem num período de tempo relativamente extenso e estável. Ora, se o Futuro Simples remetesse para a expressão de um intervalo não presente, uma leitura de sobreposição ao momento da enunciação seria, senão preferencial, pelo menos admissível neste tipo de contextos, ao contrário do que os factos nos revelam.

O que os dados que temos vindo a analisar nos sugerem é que a interpretaçáo de sobreposição ao momento da enunciação propiciada pelo Futuro Simples se constitui como uma leitura relativamente marcada, no sentido em que (i) não é preferencial, mesmo em contextos em que nada impede o seu surgimento e (ii) está sujeita a fortes restriçóes, em particular de natureza aspetual.

Estas observaçôes indiciam que, na base, o Futuro Simples remete, de uma forma ou de outra, para algum tipo de prospetividade. Como conciliar, então, o seu potencial para a localização das situaçóes num intervalo futuro com as denominadas interpretaçóes conjeturais, que supôem a sobreposição ao momento da enunciação?

Consciente de algumas das dificuldades que acabámos de apontar, Gennari (2000; 2002) propóe, para o Futuro Sintético do espanhol, um tratamento que envolve a consideração simultânea e integrada de fatores temporais, modais e aspetuais.

Gennari postula, primeiramente, que o Futuro Sintético veicula, de modo consistente, informação temporal de posterioridade. A adoção de uma abordagem deste género permite explicar a obrigatoriedade da ocorrência dos eventos num intervalo que é ulterior a $t 0$, revelando-se, por outro lado, totalmente incompatíveis com as leituras conjeturais de sobreposição ao momento da enunciação. Tendo em vista que os eventos estabelecem uma relação de inclusão com o respetivo intervalo de realização (i.e., a totalidade do evento deve estar incluída no intervalo em causa), tal como previsto, por exemplo, por Kamp \& Rohrer (1983) ou por Kamp \& Reyle (1993), e que, dadas as suas propriedades temporais, o Futuro Simples impóe que este se localize num domínio futuro, a única interpretação possível para as eventualidades em questão será a que situa as predicaçóes num intervalo posterior ao momento da enunciação. ${ }^{20}$

Ora, se o Futuro Simples exprimisse um intervalo de tempo capaz de incluir o momento da enunciação, frases como as que se seguem, com uma leitura de sobreposição dos eventos a $t 0$, seriam perfeitamente admissíveis, ao contrário do que realmente sucede:

20. Veja-se, no entanto, Rocci (2000), que nos oferece uma explicação alternativa para estes factos. 
(39) \# A Beatriz nadará na piscina neste momento. (processo)

(40) \# O Rui escreverá o seu artigo neste momento. (processo culminado)

(41) \# A ponte cairá neste momento. (culminação)

(42) \# A águia baterá as asas neste momento. (ponto) ${ }^{21}$

Vejamos, agora, o que acontece com as predicaçóes de cariz estativo. Como já referimos, e para além da interpretação em que se verifica a sua completa posterioridade com respeito ao momento da enunciação (cf. 43-44), são possíveis as designadas leituras conjeturais ou hipotéticas, em que a possibilidade de ocorrência do estado é encarada em relação a um intervalo que tipicamente inclui to (cf. 45-46):

(43) Nesta sessão estará (= vai estar) presente Roque Rodrigues, representante da resistência timorense em Portugal, e a apresentação do trabalho estará (= vai estar) a cargo de Barbedo de Magalhães, responsável pelas Jornadas de Timor da Universidade do Porto. (CetemPúblico par=ext1005494-nd-95b-2)

(44) Orçada em cerca de 400.000 contos, a nova ponte terá (= vai ter) cerca de 600 metros de extensão, e irá servir uma população de aproximadamente 150.000 pessoas, de ambos os lados do rio Minho, passando a constituir uma ligação da Galiza interior ao litoral. (CetemPúblico, par=ext132962-soc-94a-1)

(45) A vaga de calor que assolou o país durante o dia de ontem estará (= deve estar) na origem do grande número de incêndios registado, enquanto os homens que participam no combate às chamas se mostram cautelosos a apontar, para já, outras razôes. (CetemPúblico, par=ext1403391-nd-91a-1)

(46) O Público apurou que Konis Santana terá (= deve ter) cerca de trinta anos e é natural de Lautém Los Palos, na ponta leste de Timor, onde o seu pai desempenhava funções na administração local. (CetemPúblico, par=ext169831-pol-93b-1)

Assim, por exemplo, o estado representado por "Konis Santana ter cerca de trinta anos", em (46), não é perspetivado como uma eventualidade que vai ocorrer num qualquer intervalo futuro, mas, pelo contrário, como uma possibilidade a avaliar num período de tempo que inclui o momento da enunciação. Quererá isto dizer que o Futuro Simples, em casos como estes, é desprovido de informação temporal?

A resposta dada por Gennari, e que subscrevemos neste trabalho, é negativa. $\mathrm{Na}$ realidade, e tal como sucede em todos os restantes casos, também no designado fu-

21. Sublinhamos, uma vez mais, que a leitura que aqui está em causa é a de sobreposição ao momento da enunciação, sendo possível, pelo menos para alguns falantes e em certos contextos muito particulares, interpretar estas frases como futuros imediatos, interpretação essa que, no entanto, não oferece qualquer problema à análise que estamos a expor. 
turo conjetural o Futuro Simples localiza a situação com que coocorre num intervalo posterior ao momento da enunciação. Contudo, e ao contrário do que observámos para os eventos, as predicaçóes estativas que figuram neste tipo de frases, devido ao seu caráter totalmente homogéneo (i.e., à sua estrita obediência ao princípio dos subintervalos, tal como formulado em Dowty (1979)), estabelecem com o respetivo intervalo de realização uma relação de sobreposição, podendo, nessa medida, prolongar-se indefinidamente para além dos seus limites.

Ora, revelando a capacidade de se estenderem para além do intervalo futuro em que inicialmente são localizadas, as predicaçóes estativas manifestam a possibilidade de ocupar um período mais vasto de tempo que, em circunstâncias adequadas, poderá mesmo abranger o momento da enunciação, dando, assim, lugar às designadas leituras hipotéticas ou conjeturais ilustradas em exemplos como (45)-(46). O facto de a relação temporal se mostrar menos relevante neste género de estruturas explicaria, por outro lado, a forte tendência para a sua interpretaçáo como veículo privilegiado para a expressão de valores modais.

É importante sublinhar que esta diferença de comportamento linguístico ostentada por eventos e estados em relação aos respetivos intervalos de realização em termos de inclusão ou de sobreposição não serve apenas para dar conta das restriçôes patenteadas pelo futuro conjetural; ela é independentemente requerida para explicar outros fenómenos linguísticos de âmbito mais geral, nomeadamente no que diz respeito às relaçôes entre eventualidades no discurso (cf., por exemplo, os trabalhos desenvolvidos por Kamp \& Rohrer (1983) ou por Kamp \& Reyle (1993)).

Tal como seria de esperar, se os eventos forem, de alguma forma, convertidos em estados, por exemplo através da aplicação do operador de progressivo (cf. Moens 1987; Cunha, 1998) ou da integração em estruturas quantificacionais de natureza habitual (cf. Smith 1991; Chierchia 1995; Lenci 1995; Lenci \& Bertinetto 2000; Bertinetto \& Lenci 2012; Cunha 2006), podem, sem dificuldade, receber uma leitura de tipo conjetural ou hipotético, como os exemplos que se seguem nos comprovam:

(47) Outros analistas estão alarmados porque o "pipeline» atravessa a montanha Tarhuna, onde Kadhafi estará a construir, de acordo com informaçóes dos serviços de espionagem americanos e europeus, uma central de armas químicas e biológicas. (CetemPúblico, par=ext5944-pol-97b-1) (estado progressivo)

(48) Starr estará a investigar se Clinton pediu ao seu conselheiro Vernon Jordan para convencer Monica Lewinsky a mentir sobre a alegada relação entre ambos. (CetemPúblico, par=ext39141-nd-98a-1) (estado progressivo)

(49) O outro será um «czar da sida» (na nomenclatura em uso em Washington), cujo nome também se desconhece por enquanto e que trabalhará directamente com o inquilino da Casa Branca. (CetemPúblico, par=ext139614-clt-soc-93a-2) (estado obtido por quantificação de situaçóes) 
(50) Os traficantes que estão a ser investigados pela polícia comprarão (= compram habitualmente) droga na Colômbia para a venderem em Portugal. (estado obtido por quantificação sobre situaçôes) ${ }^{22}$

Sintetizando as observaçóes que efetuámos até ao momento, podemos dizer que: (i) o Futuro Simples veicula consistentemente informação temporal de posterioridade em relação ao momento da enunciação; (ii) quando combinado com eventos, e tendo em vista que, tipicamente, estes se encontram incluídos no respetivo intervalo de realização, a única leitura possível é a de prospetividade (cf. a anomalia de exemplos como [39]-[42]); (iii) quando combinado com estados, básicos ou derivados, e dado que estes se sobrepóem ao respetivo intervalo de realização, podendo prolongar-se para além das suas fronteiras, mostra-se compatível com dois tipos diferentes de interpretação: (iiia) se o estativo ocupa um intervalo de tempo que se situa integralmente no futuro (i.e., não abrange o momento da enunciação), as leituras resultantes serão de natureza prospetiva (cf. [43]-[44]); (iiib) se, pelo contrário, o estativo se estende num intervalo que compreende o momento da enunciação, então obteremos as designadas interpretaçôes hipotéticas ou conjeturais, cuja avaliação é feita em relação a tO.

Gennari (2002) apresenta argumentos adicionais que sustentam a ideia de que o Futuro Simples manifesta uma componente temporal que não pode ser ignorada.

Assim, por exemplo, a autora observa que, no contexto de oraçóes completivas, o Futuro Simples localiza a situação com que coocorre num tempo que é necessariamente posterior ao momento da enunciação, não podendo tomar o intervalo fornecido pelo verbo representado na matriz como Ponto de Perspetiva Temporal, tal como o contraste que se segue nos comprova:

(51) Há três dias, o músico disse aos jornalistas que dará um concerto na próxima sexta-feira.

22. Alternativamente, Soto (2008) sugere que seria o fator duratividade que permitiria explicar as restriçôes quanto à possibilidade vs impossibilidade de ocorrência de leituras conjeturais. Contudo, pelo menos para o Português Europeu, a análise proposta em Gennari parece ser mais adequada: se, tal como Soto preconiza, o traço [+durativo] associado à situação licenciasse, para o Futuro Simples, interpretaçôes de tipo conjetural, i.e., de sobreposição ao momento da enunciação, frases como "\# Agora a Maria viajará” ou “\# A Ana cantará neste momento” teriam de ser consideradas perfeitamente aceitáveis (a par de estruturas como "Agora o João estará na Austrália” ou “O Pedro terá 200000 euros na conta bancária neste momento"), o que, no entanto, não se verifica. A conversão dos processos em estados, por exemplo através do operador de Progressivo, torna, tal como previsto na solução que aqui preconizamos, as construções perfeitamente aceitáveis numa leitura conjetural de sobreposição ao momento da enunciação, dado um contexto adequado (cf. "[Como tirou um mês de férias], agora a Maria estará a viajar”; “[São dez horas e o espetáculo já deve ter começado há meia hora]. A Ana estará a cantar neste momento"). 
(52) * Há três dias, o músico disse aos jornalistas que dará um concerto ontem.

A agramaticalidade de frases como (52) sugere que o Futuro Simples manifesta marcas de temporalidade bastante evidentes e, em particular, que se trata de um tempo dêitico, na medida em que a localização das predicaçóes com que se combina terá de ser forçosamente efetuada em relação ao momento da enunciação. ${ }^{23}$

Sublinhe-se que, independentemente das relações temporais que estabelece, o Futuro Simples não deixa de veicular, igualmente, valores modais: na verdade, Gennari encara esta forma verbal como um operador dual que expressa, em simultâneo, tempo e modalidade.

Se uma análise como a avançada por Gennari (2000; 2002) parece perfeitamente adequada para dar conta das propriedades temporais manifestadas pelo Futuro Simples em Português Europeu, coloca, no entanto, um desafio interessante se nos detivermos na caracterização semântica de uma outra estrutura que tipicamente expressa prospetividade nesta língua, a construção ir + Infinitivo.

Com efeito, e como veremos na próxima secção deste trabalho, embora ambas as formas remetam para a localização futura das situaçôes com que se combinam, existem divergências interpretativas que parecem reclamar um tratamento diferenciado para cada uma das configuraçóes. Em particular, a construção ir + Infinitivo, ao contrário do Futuro Simples, não permite, mesmo quando estấo envolvidas predicaçóes de cariz estativo, a efetivação das designadas leituras hipotéticas ou conjeturais em que a eventualidade é avaliada em relação ao momento da enunciação.

No sentido de encontrar respostas satisfatórias para o problema que aqui se coloca, procederemos, em seguida, a uma breve comparação entre as restriçôes manifestadas, ao nível temporal, pelo Futuro Simples e pela construção ir + Infinitivo e procuraremos explorar algumas hipóteses que nos possibilitem lidar com as divergências observadas.

23. Na análise que propóe para a estrutura ir + Infinitivo no Português, e que admite poder ser igualmente aplicável às formas sintéticas do futuro, Móia (2017) sugere que este tempo gramatical tanto pode estabelecer uma relaçáo locativa com o momento da enunciação como com um qualquer outro intervalo disponibilizado no texto. No entanto, e para o que aqui nos importa, devemos sublinhar que, de um modo direto ou indireto, o Futuro Simples expressa obrigatoriamente posterioridade relativamente ao momento da enunciação e é nesse sentido que o designamos, no presente trabalho, como um tempo dêitico, independentemente das relaçóes temporais que possa estabelecer com outro tipo de intervalos representados no discurso. 


\section{Propriedades temporais do Futuro Simples e da construçáo ir + Infinitivo: semelhanças e diferenças}

$\mathrm{Na}$ sequência da maior parte dos estudos que mencionam esta forma no Português (cf., entre outros, Oliveira \& Lopes 1995; Silva 1997; Oliveira 2013; Cunha 2015; Móia 2017 ${ }^{24}$ ), consideraremos que a construção ir (no Presente do Indicativo) + Infinitivo localiza as situaçóes com que coocorre num intervalo futuro, funcionando, assim, como um tempo gramatical que expressa uma relação temporal de posterioridade. ${ }^{25}$

24. Para uma perspetiva bastante distinta no que respeita às semelhanças e divergências entre o Futuro Simples e a construção ir + Infinitivo, de base eminentemente diacrónica, vejam-se, e.g., Fleischman (1982), Lima (2001) ou Brocardo (2018).

25. Nessa medida, afastamo-nos de análises como as avançadas por Vet (1994), que, para o Francês, sugere que a construção aller + Infinitivo dá conta, no momento da enunciação, de um estado preparatório que tipicamente precede a eventualidade representada na predicaçáo principal, ou por Bravo Martín (2008), que considera a configuração ir a + Infinitivo do Espanhol como uma manifestação do aspeto prospetivo, i.e., como descrevendo não a situaçấo em si mesma mas o estado de coisas conducente à sua concretização. Essencial para a validaçâo de abordagens deste género parece ser a associação da construçáo perifrástica com um traço de relevância atual que permita, num intervalo presente, justificar a existência de um estado de coisas de algum modo articulado com a efetiva realizaçâo da predicação descrita. Ora, no que se refere ao Português Europeu, tal condição parece não se encontrar satisfeita. Por um lado, ir + Infinitivo pode adequadamente referir situaçôes que se localizam num intervalo de tempo de tal forma distante do "agora" enunciativo, ou em que não faz sentido conceber a intervenção de um agente planificador, que não será razoável associá-las a uma qualquer fase pré-preparatória relevante no momento da enunciação (cf. [i]):

(i) No relatório do Painel Intergovernamental sobre as Alteraçóes Climáticas (IPCC, na sigla em Inglês) é feita a previsão de que o nível do mar vai subir entre 26 e 82 centímetros até 2100, segundo o texto do documento citado pela agência France Presse. (exemplo retirado do artigo "Subida do nível do mar pior do que previsto ameaça milhōes de pessoas", Jornal de Notícias, 25 de setembro de 2013, disponível online em https://www.jn.pt/sociedade/interior/subida-do-nivel-do-mar-pior-do-que-previsto-ameaca-milhoes-de-pessoas-3441451. html. (11/01/2019)

Por outro lado, é possível encontrar contextos em que a construção ir + Infinitivo manifesta valores inequivocamente modais, como sucede em condicionais hipotéticas do género de "Se eu ganhar o euromilhôes, vou comprar uma mansão enorme" ou "Se um asteroide colidir com a Terra, muitos animais vão desaparecer". Em frases como estas, a probabilidade de a situaçấo representada na prótase acontecer é concebida como relativamente baixa, i.e., não é propriamente expectável que eu ganhe o euromilhóes ou que um asteroide colida com a Terra. No entanto, a construçáo ir + Infinitivo é licenciada na apódose, mesmo que as probabilidades de a eventualidade em questáo vir a ter lugar no mundo real sejam muito reduzidas. Por outras palavras, em casos como estes a noção de relevância atual, concebida como a presença de um estado pré-preparatório que decorre no momento da enunciação e que conduz, de forma mais ou menos inevitável, à realização da situação futura, parece não se verificar de todo. 
No entanto, e ao contrário do que observámos em relação ao Futuro Simples, ir + Infinitivo não parece ser compatível com leituras em que se verifica a sobreposição da eventualidade descrita com o momento da enunciação, ainda que as condiçôes aspetuais relevantes se encontrem asseguradas. Ou seja, tal como o contraste seguinte nos revela, a construção ir + Infinitivo não desencadeia valores modais de conjetura ou probabilidade e, além disso, requer que a eventualidade representada se localize num intervalo posterior ao momento da enunciação, mesmo que a predicação em causa seja de natureza estativa.

(53) A sondagem mostrou que a popularidade de Major, nas últimas semanas, caiu cinco por cento e que o Partido Trabalhista estará agora nove pontos à frente dos conservadores. (CetemPúblico, par=ext102062-nd-91a-1)

(54) \# A sondagem mostrou que a popularidade de Major, nas últimas semanas, caiu cinco por cento e que o Partido Trabalhista vai estar agora ${ }^{26}$ nove pontos à frente dos conservadores.

(55) Antes de feitas todas as contas, o vice-presidente Fernando Gomes garantiu que o FC Porto terá agora mais de 112.500 sócios, a que corresponde um encaixe directo de mais de 60 mil contos (cada novo associado pagou três meses de quotas). (CetemPúblico, par=ext77150-des-95a-1)

(56) \# Antes de feitas todas as contas, o vice-presidente Fernando Gomes garantiu que o FC Porto vai ter agora mais de 112.500 sócios, a que corresponde um encaixe directo de mais de 60 mil contos [...].

Se, todavia, suprimirmos o adverbial agora, que favorece inequivocamente uma leitura de sobreposição com o momento da enunciaçáo, as frases com ir + Infinitivo tornam-se bastante mais aceitáveis, desde que as situaçóes descritas sejam interpretadas como decorrendo num intervalo obrigatoriamente posterior ao momento da enunciação (cf. 57-58):

(57) A sondagem mostrou que a popularidade de Major, nas últimas semanas, caiu cinco por cento e que o Partido Trabalhista vai estar nove pontos à frente dos conservadores.

(58) Antes de feitas todas as contas, o vice-presidente Fernando Gomes garantiu que o FC Porto vai ter mais de 112.500 sócios, a que corresponde um encaixe directo de mais de 60 mil contos [...].

26. Sublinhe-se que, nos exemplos apresentados, apenas consideramos a interpretação estritamente temporal de "agora", equivalente a "neste momento"; quaisquer outras aceçóes associadas a este adverbial serão ignoradas, na medida em que não são relevantes para a discussão que estamos a levar a cabo. 
Em suma, constatamos que, enquanto o Futuro Simples, combinado com estativos, possibilita o estabelecimento de uma relação de sobreposição das situaçóes a que se aplica com o momento da enunciação, conferindo-lhes tipicamente uma interpretação modal de probabilidade, a construção ir (no Presente do Indicativo) + Infinitivo, em idênticas circunstâncias, apenas licencia leituras temporais de posterioridade.

Importa, por conseguinte, tentar encontrar uma explicação para esta assimetria, ao nível do comportamento temporal, que se verifica entre o Futuro Simples e a construção ir + Infinitivo.

Uma primeira hipótese, inspirada em observaçóes como as efetuadas por Oliveira (1986) para o Português ou por Escandell-Vidal (2018) para o Espanhol, poderia passar por considerar que esta divergência se deve ao facto de o Futuro Simples exprimir preferencialmente valores modais, contrastando com a estrutura ir + Infinitivo, que remeteria primordialmente para a manifestação de relaçóes de cariz temporal.

Se nos parece indiscutível que, na realidade, o Futuro Simples se revela mais apto para a expressão da modalidade comparativamente com a construção ir + Infinitivo, este facto não poderá, em nosso entender, ser invocado como o principal responsável pela assimetria que acabámos de apresentar.

Em primeiro lugar, como procurámos deixar claro ao longo do presente trabalho, o Futuro Simples manifesta consistentemente valores temporais de posterioridade, não devendo, por conseguinte, ser encarado como um operador exclusivamente modal (a este respeito veja-se, igualmente, Cunha (2019)). Em particular, e como sublinhámos na Secção 2, existe um conjunto alargado de contextos que inequivocamente favorecem uma interpretação essencialmente temporal desta forma verbal, em particular aqueles em que as proposiçóes veiculam um alto grau de certeza, descrevem acontecimentos concebidos como inevitáveis ou necessários ou em que as situações são localizadas em intervalos precisos no eixo do futuro.

Em segundo lugar, é importante notar que a construção ir + Infinitivo pode estar envolvida em configuraçóes de natureza claramente modal, como é o caso das oraçóes condicionais hipotéticas que apresentamos em seguida:

(59) "Se ganhar a questão em tribunal, vou pedir-lhe uma indemnização de 200 mil contos." (CetemPúblico, par=ext317378-soc-98a-2)

(60) "Se receber os votos necessários, vou mudar a cor do cabelo para verde... um verde berrante." (CetemPúblico, par=ext466887-des-94a-1)

(61) "Se chover muito, as culturas de sequeiro vão ser prejudicadas e vai ser mais difícil trabalhar a terra." (CetemPúblico, par=ext309358-nd-92a-1)

Tendo em conta que as prótases das condicionais em (59-61) são apresentadas como meras possibilidades ou como simples hipóteses, as respetivas apódoses, em que figura a construção ir + Infinitivo, exprimem, igualmente, um elevado grau de incerteza. Nesse sentido, as situaçóes de "pedir uma indemnização de duzentos mil 
contos" em (59), de "mudar a cor do cabelo para verde" em (60) ou de "as culturas de sequeiro serem prejudicadas" em (61) não são dadas como garantidas ou como asseguradas num intervalo futuro em relação ao mundo de referência, mesmo que a forma verbal que nelas participa seja a estrutura ir + Infinitivo.

Por outro lado, a construção ir + Infinitivo parece ser perfeitamente admissível no contexto de adverbiais, do género de possivelmente ou de dificilmente, que remetem para um certo grau de dúvida no que respeita à realização das eventualidades com que se combinam. Tal comportamento estaria de acordo com a hipótese de que, em condiçóes favoráveis, se verifica uma clara compatibilidade da referida estrutura com leituras de natureza modal.

(62) Mas, assim como o nosso natural multilinguismo é fraqueza que joga a nosso favor, não seria mau que olhássemos com outra atenção para o que se está a passar no centro da Europa, onde se redistribui o jogo que possivelmente vai marcar a parada europeia no próximo século. (CetemPúblico, par=ext482388-opi-98b-1)

(63) O pior é que o Governo mostra, na definição do novo QCA, uma estratégia que dificilmente vai alterar o actual status quo. (CetemPúblico, par=ext105091-eco-94b-1)

(64) De concreto, fica-se a saber pela leitura do relatório que Portugal dificilmente vai utilizar os 140 milhôes de contos disponibilizados pelo PEDAP ou que o emparcelamento decorre de forma "muito lenta". (CetemPúblico, par=ext764022-eco-95b-2)

Assim, por exemplo, numa frase como (64), e dada a informação veiculada pelo adverbial dificilmente, não é possível asserir que, no mundo real, Portugal "vai utilizar os 140 milhóes de contos disponibilizados pelo PEDAP" num intervalo futuro. Por outras palavras, a estrutura ir + Infinitivo, pelo menos em casos como estes, não é suficiente para assegurar a veracidade da proposição com que se combina, podendo compatibilizar-se facilmente com as interpretaçôes modais atribuídas às predicaçôes em que ocorre. ${ }^{27}$

Em suma, e tendo em conta que (i) o Futuro Simples exibe marcas inequívocas de temporalidade, na medida em que, num vasto conjunto de contextos, a sua função central parece ser a de localizar as situaçôes com que surge num intervalo posterior ao momento da enunciaçáo e (ii) a construçáo ir + Infinitivo pode estar envolvida em configuraçóes de natureza modal, não nos parece totalmente adequada a hipótese

27. O facto de a construçáo ir + Infinitivo se encontrar por vezes associada à expressão da modalidade não parece restringir-se ao Português Europeu. Com efeito, autores como Bravo Martín (2008) ou Kornfeld (2014) referem que a estrutura equivalente no espanhol, ir $a+$ Infinitivo, é igualmente capaz de exprimir valores modais em contextos adequados. 
segundo a qual a capacidade de sobreposição ao momento da enunciação manifestada pelo Futuro Simples se deve, em exclusivo, às propriedades modais que lhe estariam associadas.

Além do mais, uma solução que associasse diretamente o potencial de exprimir valores modais com a variação nas relaçôes temporais observadas não seria capaz, por um lado, de explicar cabalmente as divergências que se observam entre estados e eventos no que diz respeito às suas (im)possibilidades de comparência nas designadas construçóes conjeturais que caracterizam o Futuro Simples, tal como discutido na secçáo anterior, na medida em que não tem em consideração o papel desempenhado pelos fatores aspetuais; por outro, prediria, erroneamente, que, em casos em que a estrutura ir + Infinitivo se revela compatível com uma interpretação modal, a sua leitura de sobreposição ao momento da enunciação seria licenciada. Comparem-se os seguintes exemplos:

(65) O João dificilmente estará na faculdade neste momento, porque ontem teve um acidente e foi para o hospital.

(66) \# O João dificilmente vai estar na faculdade neste momento, porque ontem teve um acidente e foi para o hospital.

(67) O João dificilmente vai estar na faculdade amanhã, porque ontem teve um acidente e foi para o hospital.

Parece claro que, numa frase como (66), a construçáo ir + Infinitivo recebe uma interpretação de cariz modal, o que pode ser atestado pela presença de um adverbial como dificilmente; tal facto, por si só, não acarreta, no entanto, a viabilização de uma leitura de sobreposição da situação em causa ao momento da enunciação. Sublinhe-se que, como já observámos atrás e o exemplo (67) comprova, a estrutura sob análise é perfeitamente compatível com a expressão da modalidade em contextos em que a eventualidade descrita é projetada num intervalo futuro.

Da discussão realizada até ao momento podemos concluir que a impossibilidade de ir + Infinitivo estabelecer uma relação de sobreposição com o momento da enunciação não pode, de forma alguma, ser correlacionada com a ideia de que tal estrutura se revela incapaz de integrar contextos claramente modais.

Esta constatação leva-nos a considerar a hipótese de que, embora dando origem a uma relaçáo consistente de posterioridade, o Futuro Simples e a construção ir + Infinitivo diferem no que respeita ao tipo de relações temporais em que se encontram envolvidos.

A ideia de que a construção ir (no Presente do Indicativo) + Infinitivo e o Futuro Simples se encontram associados a estruturas temporais distintas remonta a trabalhos como os de Reichenbach (1947). Tomando como base de análise as formas do Inglês will e be going to, o autor considera que, efetivamente, existem diferenças subjacentes a estas configuraçóes que sustentam a adoção de representaçôes semânticas divergentes. 
Assim, e assumindo que TE representa o tempo da enunciação, TR o tempo de referência e TS o tempo da situação, Reichenbach sugere que a forma will localiza as situaçôes na esfera do futuro, correspondendo a uma representação do género de TE-TR, TS ${ }^{28}$, ao passo que a construção be going to pertence à esfera do presente, sendo, por isso, representada por TE,TR-TS. ${ }^{29}$

Estas duas representações espelhariam uma diferença fundamental entre as configuraçôes em análise: ao passo que will estabelece uma perspetiva a partir do futuro - o que se reflete na posterioridade do Tempo de Referência em relaçáo ao Tempo da Enunciação -, a estrutura be going to privilegia uma perspetiva a partir do presente, traduzida na relaçáo de sobreposiçáo que se observa entre o Tempo de Referência e o Tempo da Enunciação. ${ }^{30}$

Silva (1997) adota, para o Português do Brasil, uma abordagem semelhante com vista a dar conta das divergências entre as duas formas de exprimir futuridade de que nos temos vindo a ocupar nesta secção. Em particular, assume que a simultaneidade entre o Tempo de Referência e o Tempo da Enunciação é a consequência esperada da noção de relevância atual que caracterizaria a perífrase $i r$ + Infinitivo. ${ }^{31}$

Um tratamento deste género não se adequa, todavia, aos dados que observámos para o Português Europeu. Ao contrário do que sucede noutras línguas, a construção ir + Infinitivo em PE não pode ser identificada, no que respeita aos seus traços semânticos fundamentais, a partir de conceitos como os de proximidade temporal ao momento da enunciação, de imediatez, de iminência, de inevitabilidade ou de intencionalidade.

$\mathrm{Na}$ realidade, constatamos que nenhuma destas propriedades parece poder ser considerada como identificadora da construção em apreço. Nesse sentido, um exemplo como (68) mostra que ir + Infinitivo pode localizar situaçóes num intervalo relativamente distante do momento da enunciação, não expressando, por conseguinte, imediatez ou iminência; uma frase como a de (69) revela que a estrutura em questão pode descrever estados de coisas não intencionais (i.e., em que não está presente um sujeito planificador) e, por fim, (70) confirma que a realização das eventualidades expressas por ir + Infinitivo não pode ser tomada como inevitável, na medida em que suporta a manifestação de dúvida ou de incerteza quanto à sua concretização.

28. TE-TR,TS pode ser parafraseado por: o tempo da enunciação é anterior ao tempo de referência, que, por sua vez, coincide com o tempo da situação.

29. TE,TR-TS pode ser parafraseado por: o tempo da enunciação coincide com o tempo de referência; por sua vez, estes dois intervalos são anteriores ao tempo da situação.

30. Para uma análise mais aprofundada das diferenças entre will e be going to no Inglês, veja-se também Copley (2009).

31. Como mais um argumento em favor desta análise, Silva (1997) assinala que o uso do Presente do Indicativo associado ao semiauxiliar ir seria o reflexo morfológico da relação de sobreposição entre o Tempo da Enunciação e o Tempo de Referência. 
(68) Ou seja: estamos a falar de algo que só se vai materializar nas mãos dos utilizadores daqui a seis meses. (CetemPúblico, par=ext378164-clt-soc-95a-2)

(69) Nestes dias a neve também vai cair com alguma intensidade no Norte do país e na serra da Estrela, mas a ligeira subida de temperatura prevista para quinta-feira deverá alterar a paisagem branca que ainda se observa em muitas zonas. (CetemPúblico, par=ext580642-soc-96a-1)

(70) Entretanto afirma-se arrependido mas pensa que isso dificilmente vai pesar na decisão do Comité Olímpico Internacional (COI), que vai reunir a pedido da Federação Internacional de Halterofilismo. (CetemPúblico, par=ext1159943-des-92b-1)

Para além de não dar uma resposta satisfatória aos sérios problemas empíricos levantados por um vasto conjunto de contextos, a análise proposta por Silva (1997) para a distinção entre ir + Infinitivo e o Futuro Simples também não é capaz de fornecer uma explicação credível para a alternância que temos vindo a discutir ao longo do presente trabalho.

Com efeito, e partindo do princípio de que a construção ir (no Presente do Indicativo) + Infinitivo se caracteriza pela simultaneidade entre o Tempo de Referência e o Tempo da Enunciaçáo, a estrutura em causa acabaria por ser a candidata mais credível para a emergência de leituras de sobreposição a t0 quando estão envolvidas predicaçóes estativas, dado que, como vimos, estas podem prolongar-se para além das fronteiras do seu intervalo de ocorrência, situado no futuro, e o respetivo Tempo de Referência favoreceria uma relação mais estreita com o momento da enunciação. No entanto, é com o Futuro Simples - em que o Tempo de Referência é concebido como posterior ao Tempo da Enunciação - que as interpretaçóes de sobreposição ao presente são viabilizadas.

Como solucionar, então, este problema, i.e., como explicar o facto de que apenas o Futuro Simples - e não a construção ir + Infinitivo - pode integrar configuraçóes conjeturais em que se verifica sobreposição ao momento da enunciação?

Embora estejamos plenamente conscientes das inúmeras diferenças entre tempos do passado e tempos do futuro - nomeadamente no que diz respeito ao caráter ramificante destes últimos -, uma breve incursão pelas propriedades semânticas do Pretérito Perfeito e do Imperfeito do Indicativo poderá ajudar-nos a descrever a assimetria que temos vindo a discutir ao longo da presente secção.

No Português Europeu, os dois principais tempos que localizam uma situação num intervalo anterior ao momento da enunciaçáo - Pretérito Perfeito e Pretérito Imperfeito do Indicativo - diferem consideravelmente no que se refere às (im) possibilidades de prolongamento das eventualidades com que se combinam até ao momento presente. Observem-se os seguintes contrastes: 
(71) \# O João esteve doente e, na verdade, ainda está.

(72) O João estava doente e, na verdade, ainda está.

(73) \# A Rita morou em Londres e, possivelmente, ainda lá mora.

(74) A Rita morava em Londres e, possivelmente, ainda lá mora.

É com base neste género de exemplos que autores como Cipria \& Roberts (2000) ou Cunha $(2007 ; 2013)$ defendem a ideia de que, ao contrário do Imperfeito, o Pretérito Perfeito é um tempo terminativo. ${ }^{32}$

Em termos gerais, a terminatividade pode ser caracterizada como a imposição de uma fronteira final (ou término) às eventualidades envolvidas, não lhes sendo possível ultrapassar esse limite temporal, independentemente das propriedades aspetuais que exibam.

Assim, mesmo quando estão envolvidas predicações estativas, como sucede com exemplos como (71) e (73), as situaçóes que ocorrem no Pretérito Perfeito não só estão localizadas num intervalo do passado como também não se podem expandir para além do término que lhes é imposto, o que se traduz, neste caso, na impossibilidade do seu prolongamento até ao momento da enunciação. ${ }^{33}$

O Pretérito Imperfeito, em contrapartida, no que diz respeito à informação temporal que veicula, apenas localiza as situaçóes com que coocorre num intervalo do passado. Isto significa, em última instância, que, quando estão em causa predicaçôes de natureza estativa, estas se podem estender para além do respetivo tempo de referência, sobrepondo-se mesmo, em contextos adequados, ao momento da enunciação, como (72) e (74) nos sugerem..$^{34}$

Assim, podemos afirmar que o Pretérito Perfeito é, em termos temporais, mais restritivo do que o Imperfeito, na medida em que não se limita a proceder à localização de uma situação num intervalo passado, impondo-lhe, adicionalmente, uma

32. Sublinhe-se que assumimos aqui que o Pretérito Perfeito é um tempo terminativo e não perfetivo, na medida em que náo revela a capacidade de alterar as propriedades aspetuais básicas das eventualidades com que se combina, i.e., não interfere, por exemplo, com a telicidade das situaçóes envolvidas. É por essa razão que é considerado em PE um tempo relativamente "neutro" e pode ser utilizado para estabelecer distinçôes entre as diferentes classes aspetuais. Para uma discussão mais aprofundada destas questôes, veja-se Cunha (2007) e a comparação entre as possibilidades interpretativas do Pretérito Perfeito Simples e do Pretérito Perfeito Composto nas várias línguas românicas apresentada por Squartini $\&$ Bertinetto (2000).

33. Por uma questáo de simplicidade de exposição, estamos a assumir aqui que o Ponto de Perspetiva Temporal para o Pretérito Perfeito é sempre o momento da enunciação; no entanto, em casos em que seja outro o PPT selecionado, o mesmo tipo de observaçóes poderá aplicar-se, dadas as devidas adaptaçóes.

34. Para além do seu valor temporal, o Imperfeito, em termos aspetuais, parece comportar-se como um verdadeiro estativizador (cf. Kamp \& Rohrer 1983; Cunha 2007; Oliveira 2013). Dado que não é nosso objetivo, no presente trabalho, aprofundar problemas de índole eminentemente aspetual, deixaremos de lado, por ora, a discussão desta questão. 
fronteira final para além da qual a eventualidade descrita não se poderá prolongar, seja qual for o perfil aspetual básico que a caracteriza.

Uma outra propriedade que permite distinguir o Pretérito Perfeito e o Imperfeito do Indicativo prende-se com a expressão de valores modais. $\mathrm{Na}$ realidade, o Pretérito Perfeito raramente recebe interpretaçóes que remetam para a modalidade, ao contrário do que sucede com o Imperfeito, que, como é sabido, se compatibiliza perfeitamente com este género de leituras. ${ }^{35}$

A título meramente ilustrativo, considerem-se os casos do designado Imperfeito onírico ou ficcional, em que é descrito o conteúdo de sonhos ou de acontecimentos imaginários (cf. 75), do Imperfeito de cortesia, utilizado para atenuar a força ilocutória de ordens ou de pedidos (cf. 76), do Imperfeito de planificação, que projeta para o futuro uma situação que está a ser planeada pelo locutor no momento da enunciação (cf. 77) ou do Imperfeito hipotético ou de probabilidade, que surge tipicamente no contexto de oraçóes condicionais (cf. 78):

(75) O João sonhou que um dragão $\{$ entrava / entrou\} no seu quarto e o $\{$ raptava / raptou\}.

(76) $\{$ Queria / \# Quis\} um bolo e um café, por favor.

(77) Então, amanhã, eu $\{$ vinha / * vim\} mais cedo e $\{$ começávamos / * começámos $\}$ a reunião por volta das oito horas.

(78) Se tivesse dinheiro, eu $\{$ comprava $/ *$ comprei $\}$ um Ferrari.

Como os exemplos acima deixam bem claro, o Imperfeito parece muito mais apto a exprimir valores de cariz modal quando comparado com o Pretérito Perfeito. Tal facto leva-nos a colocar a hipótese de que, de um certo ponto de vista, podemos encontrar uma correlação entre a especialização na expressão de relaçóes temporais e a (in)capacidade para a veiculação de outro tipo de informação semântica. Com efeito, parece plausível assumir que, quanto mais restritivo um tempo gramatical é em termos da localização temporal das predicaçóes com que ocorre, menos probabilidade terá de poder manifestar outro tipo de conteúdo semântico, nomeadamente no que diz respeito à modalidade.

Com estas observaçóes em mente, regressemos agora ao problema que nos tem vindo a ocupar ao longo da presente secção, i.e., a diferença entre o Futuro Simples e a construção ir (no Presente) + Infinitivo no que à expressão da temporalidade diz respeito.

Como já referimos anteriormente, uma das divergências fundamentais que se podem constatar entre estas duas formas de manifestar a posterioridade tem a ver com

35. Para uma discussão mais alargada sobre as propriedades modais associadas ao Imperfeito, vejam-se, entre outros, Oliveira (1987), Cipria \& Roberts (2000), Ippolito (2004), Anand \& Acquard (2009) ou Arregui, Rivero \& Salanova (2014). 
o facto de o Futuro Simples ter a capacidade de localizar situaçóes em contextos de sobreposição ao momento da enunciação, ao contrário do que sucede com a estrutura ir + Infinitivo, para a qual esta opção está tipicamente vedada.

A hipótese que aqui colocaremos é a de que um tal facto deriva diretamente das diferenças, em termos de informação temporal, subjacentes a cada uma destas estruturas.

Relativamente ao Futuro Simples, e como já assinalámos no final da Secção 3, assumiremos, com Gennari $(2000 ; 2002)$, que esta forma procede à mera localização de uma dada eventualidade num intervalo posterior ao momento da enunciaçáo (ou a um PPT equivalente). Nesse sentido, e tal como observámos para o Imperfeito em relação ao passado, permite que os estativos ocupem um intervalo que se pode prolongar para além dos limites associados ao respetivo tempo de localização (no futuro), dando, assim, origem, em circunstâncias apropriadas, a uma relação de sobreposição com o momento da enunciação. Tendo em consideraçáo, por outro lado, que os eventos se encontram obrigatoriamente contidos no respetivo tempo de ocorrência e que o Futuro Simples não altera o seu perfil aspetual básico, as predicaçóes que integram a classe em questão não se revelam compatíveis com uma leitura de sobreposiçáo a t0, como o contraste entre os exemplos seguintes nos confirma:

(79) A Maria estará na Faculdade \{agora / amanhâ\}. (estado)

(80) O João terá uma conta secreta num banco suíço \{neste momento / daqui a dois anos, quando desfalcar a empresa\}. (estado)

(81) O primeiro-ministro discursará no parlamento $\left\{{ }^{*}\right.$ neste momento / amanhã de manhãu. (evento)

(82) Entretanto, o Teatro Nacional S. João apresentará, \{ ${ }^{*}$ neste momento / no próximo dia 20\}, o recital que Aprille Milo não pôde dar no Porto a 29 de Abril passado, por doença. (exemplo adaptado do corpus CetemPúblico, par $=$ ext8617-clt-94a-1) $)^{36}$ (evento)

No que respeita à construçáo ir (no Presente do Indicativo) + Infinitivo, no entanto, uma análise baseada na simples localização de uma situação num intervalo posterior ao ponto de fala revela-se manifestamente insuficiente, na medida em que prediria, erroneamente, a possibilidade de os estativos se prolongarem até ao momento da enunciação. Assim, a hipótese que aqui adiantaremos será a de que a referida estrutura, para além de projetar as eventualidades no futuro, requer a postulaçáo de

36. Sublinhe-se que, se os eventos forem convertidos em estados, por exemplo através do operador de Progressivo, a leitura de sobreposição da predicação no Futuro Simples ao momento da enunciação torna-se perfeitamente aceitável (cf. "O primeiro-ministro estará a discursar no parlamento neste momento"; "O Teatro Nacional S. João estará a apresentar, neste momento, o recital que Aprille Milo não pôde dar no Porto a 29 de Abril passado"). 
uma fronteira inicial posterior a tO para além da qual as situaçôes descritas não podem ocorrer, numa espécie de imagem em espelho do que acontece com o Pretérito Perfeito Simples no domínio do passado.

Tal como o término imposto pelo Pretérito Perfeito Simples do Indicativo impede as eventualidades de se prolongarem até ao momento da enunciação, independentemente da categoria aspetual a que pertencem e à relação que estabelecem com o respetivo tempo de ocorrência, também a fronteira inicial associada à construção ir + Infinitivo restringiria os intervalos em que as situaçóes podem ocorrer ao domínio do futuro, mesmo que, noutro tipo de circunstâncias, a sua extensão até ao presente fosse uma opção viável.

Uma análise nestes termos poderá ajudar a explicar o contraste entre frases como (79-80) e (83-84):

(83) A Maria vai estar na Faculdade \{* agora / amanhấ. (estado)

(84) O João vai ter uma conta secreta num banco suíço \{ ${ }^{*}$ neste momento / daqui a dois anos, quando desfalcar a empresa\}. (estado)

Segundo esta nossa proposta, seria, por conseguinte, a restrição temporal imposta por uma fronteira inicial localizada num intervalo posterior ao momento da enunciação que impediria os estativos de se prolongarem até ao ponto de fala nas construçóes com ir + Infinitivo, permitindo diferenciá-las do Futuro Simples, em que esta restrição adicional parece não se aplicar.

Se as observaçóes que fizemos em relação aos tempos do passado estáo corretas, a abordagem que aqui estamos a considerar acarretaria ainda uma segunda consequência que importa ter em conta. Como já referimos, quanto maiores são as restriçóes em termos de localização impostas por uma estrutura, menor seria a sua capacidade de veicular informação semântica de natureza não temporal. Isso explicaria a maior propensão por parte do Imperfeito em receber leituras de cariz modal, na medida em que se limita a localizar as eventualidades com que se combina num intervalo passado, ao contrário do Pretérito Perfeito, que, ao impor um limite terminal às predicaçóes, fornece indicaçóes temporais mais específicas e estará menos apto a integrar construçôes com interpretaçôes não estritamente temporais.

Ora, o que, segundo esta nossa abordagem, distingue o Futuro Simples da construção $i r$ + Infinitivo é o facto de a primeira forma se limitar a localizar uma situação num intervalo posterior ao momento da enunciaçáo, ao passo que a segunda, para além dessa função localizadora, acrescenta uma restrição temporal específica - a imposição de uma fronteira inicial posterior a $t 0$, que impede as eventualidades de se prolongarem até ao momento da enunciação. Não surpreende, por conseguinte, que seja o Futuro Simples - a forma que menos restriçóes temporais impóe - a receber preferencialmente valores de natureza modal, ao contrário de $i r$ + Infinitivo, que, ao ser temporalmente mais específico, parece mais propenso a integrar configuraçóes em 
que a temporalidade assume um papel de maior preponderância (embora, como tivemos oportunidade de observar, não exclua contextos em que a modalidade também está presente).

Por outras palavras, a forte associação do Futuro Simples à expressão da modalidade, que tão frequentemente é referida na literatura (cf. Oliveira 1986; Silva 1997; Sarkar 1998; Mari 2009; Oliveira 2013; Giannakidou, 2014; Giannakidou \& Mari 2018), estaria, em certa medida, fortemente relacionada com as suas propriedades temporais, em particular se tivermos em consideração o contraste que estabelece com a construção ir + Infinitivo.

\section{Conclusão}

Podemos afirmar que, em línguas como o Português, o Futuro Simples é um tempo gramatical que se reveste de um alto grau de complexidade, na medida em que se encontra associado à expressão de informação semântica muito diversificada.

Ao longo do presente trabalho procurámos demonstrar que um tratamento adequado para esta forma verbal não apenas tem de tomar em consideração questóes de natureza temporal, mas também de dar conta dos valores modais que por vezes assume.

Tendo demonstrado que a informação temporal de posterioridade em relação ao momento da enunciação (ou a outro Ponto de Perspetiva Temporal equivalente) veiculada pelo Futuro Simples se constitui como uma parte fundamental do seu significado básico, procurámos fornecer uma descrição capaz de dar conta do seu comportamento linguístico. Em particular, sugerimos que a facilidade que este tempo gramatical revela em integrar construçóes com valor modal se deve essencialmente ao facto de as indicaçóes temporais que transmite serem pouco restritivas, já que apenas requer que a situação expressa se localize num intervalo posterior ao ponto de fala.

Nesse sentido, contrasta com a estrutura ir (no Presente) + Infinitivo, que, a somar ao estabelecimento de uma relaçáo de posterioridade com o momento da enunciação, parece impor também um limite ou fronteira inicial, para além do qual as eventualidades descritas não se podem prolongar. Como consequência, e ao contrário do que sucede com o Futuro Simples, ir + Infinitivo não admite leituras de sobreposição a tO e revela-se menos apto a integrar configuraçóes em que a expressão da modalidade é preponderante.

Uma análise deste género levanta questóes muito interessantes, como a que diz respeito ao desenho de uma formalização adequada para os dois tempos gramaticais em confronto ou a relativa à discussão dos diferentes valores modais associados ao Futuro Simples, que, no entanto, teremos de deixar para trabalhos futuros. 


\section{Financiamento}

Este trabalho teve o apoio do Centro de Linguística da Universidade do Porto, unidade financiada pela Fundação para a Ciência e a Tecnologia, PEst-OE/LIN/ UI0022/2011. 


\section{Referências bibliográficas}

Alarcos Llorach, Emilio. 1961. La forme cantaría en espagnol: mode, temps et aspect. Em Actas del IX Congreso Internacional de Lingüistica Românica, 1: 203-212. Lisboa: Centro de estudos filológicos. (Republicado em Estudios de gramática funcional del español com o título "Cantaría: modo, tiempo y aspecto", 106-119).

Alarcos Llorach, Emilio. 1972. Estudios de gramática funcional del español. Madrid: Gredos.

Alarcos Llorach, Emilio. 1994. Gramática de la lengua española. Madrid: Real Academia Española / Espasa Calpe.

Anand, Pranav \& Valentine Hacquard. 2009. The role of the imperfect in Romance counterfactuals. Proceedings of Sinn und Bedeutung 14, 37-50. https://ojs.ub.uni-konstanz.de/sub/index.php/sub/ article/view/458

Arregui, Ana, María Luisa Rivero \& Andrés Salanova. 2014. Cross-linguistic variation in imperfectivity. Natural Language \& Linguistic Theory 32 (2), 307-362. https://doi.org/10.1007/s11049013-9226-4

Bello, Andrés. 1847/1988. Gramática de la lengua castellana destinada al uso de los americanos. Madrid: Arco Libros.

Bertinetto, Pier Marco \& Alessandro Lenci. 2012. Habituality, pluractionality, and gnomic imperfectivity. Em Robert Binnick (ed.), Oxford handbook of Tense and Aspect. 852-880. Oxford: Oxford University Press. https://doi.org/10.1093/oxfordhb/9780195381979.013.0030

Binnick, Robert. 1991. Time and the Verb. A Guide to Tense and Aspect. Oxford / Nova York: Oxford University Press.

Bravo Martín, Ana. 2008. La perifrasis "ir a + Infinitivo" en el sistema temporal y aspectual del Español. Madrid: Universidad Complutense de Madrid. (Dissertação de Doutoramento).

Brocardo, Maria Teresa. 2018. Usos epistémicos de «haver» e «ter» em português antigo. Revue de Linguistique Romane 82, 353-376.

Bull, William E. 1960. Time, Tense and the Verb. A Study in Theoretical and Applied Linguistics, with Particular Attention to Spanish. Berkeley: University of California Press.

Chierchia, Gennaro. 1995. Individual-level predicates as inherent generics. Em Greg Carlson \& François Pelletier (eds.), The Generic Book. 176-223. Chicago: the University of Chicago Press.

Cipria, Alicia \& Craige Roberts. 2000. Spanish imperfecto and pretérito: truth conditions and aktionsart effects in a Situation Semantics. Natural Language Semantics 8 (4), 297-347. https://doi. org/10.1023/A:1011202000582

Condoravdi, Cleo. 2003. Moods and modalities for will and would. Comunicaçáo apresentada ao Workshop on Mood and Modality, Amsterdam Coloquium. https://web.stanford.edu/_cleoc/achan.pdf

Copley, Bridget. 2009. The Semantics of the Future. New York: Routledge Outstanding Dissertations in Linguistics. https://doi.org/10.4324/9780203880258

Cunha, Celso \& Lindley Cintra. 1984. Nova Gramática do Português Contemporâneo, Lisboa: Ediçóes Sá da Costa. 
Cunha, Luís Filipe. 1998. As Construçōes com Progressivo no Português: uma Abordagem Semântica. Porto: Faculdade de Letras da Universidade do Porto. (Dissertação de Mestrado).

Cunha, Luís Filipe. 2006. Frequência vs. habitualidade: distinçôes e convergências. Em Milka Villayandre Llamazares (ed.), Actas del XXXV Simpósio Internacional de la Sociedad Española de Lingüistica. 333-357. León: SEL. http://www3.unileon.es/dp/dfh/SEL/actas/Cunha.pdf

Cunha, Luís Filipe. 2007. Semântica das Predicaçōes Estativas: para uma Caracterizaçâo Aspectual dos Estados. Munique: Lincom Europa.

Cunha, Luís Filipe. 2013. Aspeto. Em Eduardo Paiva Raposo, Maria Fernanda Bacelar do Nascimento, Maria Antónia Mota, Luísa Segura \& Amália Mendes (orgs.), Gramática do Português, Vol. I, Cap. 17. 585-622. Lisboa: Fundação Calouste Gulbenkian.

Cunha, Luís Filipe. 2015. Some remarks on the semantics of ir ('go') + Infinitive in European Portuguese. Journal of Advances in Linguistics 5 (3), 787-804. https://doi.org/10.24297/jal.v5i3.2866

Cunha, Luís Filipe. 2019. O Futuro Simples em Português Europeu: entre a temporalidade e a modalidade. Linguistica - Revista de Estudos Linguisticos da Universidade do Porto 14 (1), 35-68.

Dendale, Patrick. 2001. Le futur conjectural versus devoir épistémique: différences de valeur et restrictions d'emploi. Le Français Moderne 69 (1), 1-20.

Dowty, David. 1979. Word meaning and Montague grammar. Dordrecht: Reidel Publishing Company. https://doi.org/10.1007/978-94-009-9473-7

Escandell-Vidal, María Victoria. 2010. Futuro y evidencialidad. Anuario de Lingüistica Hispánica 26, 9-34. Valladolid: Universidad de Valladolid. http://uvadoc.uva.es/handle/10324/9480

Escandell-Vidal, Maria Victoria. 2014. Evidential futures. The Case of Spanish. Em Philippe de Brabanter, Mikhail Kissine \& Saghie Sharifzadeh (eds.), Future Tense(s), Future Time(s). 219-246. Oxford: Oxford University Press. https://doi.org/10.1093/acprof:oso/9780199679157.003.0010

Escandell-Vidal, María Victoria. 2018. El futuro simple del español. Sistema natural frente a usos cultivados. Verba Hispánica 26, 15-33. https://doi.org/10.4312/vh.26.1.15-33

Falaus, Anamaria \& Brenda Laca. 2014. Les formes de l'incertitude. Le futur de conjecture en espagnol et le présomptif futur en roumain. Revue de linguistique romane 78, 313-366.

Fleischman, Suzanne. 1982. The future in thought and language. Cambridge: Cambridge University Press.

Gennari, Silvia. 2000. Semantics and pragmatics of future tenses in Spanish. Em Héctor Campos, Elena Herburger, Alfonso Morales-Front \& Thomas J. Walsh (eds.), Hispanic Linguistics at the Turn of the Millennium: Papers from the $3^{\text {rd }}$ Hispanic Linguistics Symposium. 264-281. Somerville: Cascadilla Press.

Gennari, Silvia. 2002. Spanish past and future tenses: Less (semantics) is more. Em Javier Gutiérrez-Rexarch (ed.), From Words to Discourse: Trends in Spanish Semantics and Pragmatics. 21-36. Oxford: Elsevier.

Giannakidou, Anastasia \& Alda Mari. 2013. A two dimensional analysis of the future: modal adverbs and speaker's bias. Em Maria Aloni, Michael Frank \& Floris Roelofsen (eds.), Proceedings of the 19th Amsterdam Colloquium 2013, 115-122.

Giannakidou, Anastasia \& Alda Mari. 2018. A unified analysis of the future as epistemic modality. Natural Language \& Linguistic Theory 36 (1), 85-129. https://doi.org/10.1007/s11049-0179366-z 
Giannakidou, Anastasia. 2014. The futurity of the present and the modality of the future: a commentary on Broekhuis and Verkuyl. Natural Language \& Linguistic Theory 32 (3), 1011-1032. https:// doi.org/10.1007/s11049-014-9234-z

Giomi, Riccardo. 2010. Para uma caracterização semântica do futuro sintético românico: Descrição e análise dos valores do futuro do indicativo em Português e em Italiano.Lisboa: Faculdade de Letras da Universidade de Lisboa. (Dissertação de Mestrado).

Ippolito, Michela. 2004. Imperfect modality. Em Jacqueline Guéron \& Jacqueline Lecarme (eds.), The syntax of time. 359-387. Cambridge, MA: MIT Press.

Kamp, Hans \& Christien Rohrer. 1983. Tense in texts. Em Rainer Bauerle, Christoph Schwarze \& Arnim von Stechow (eds.), Meaning, Use and Interpretation of Language. 250-269. Berlim: Walter de Gruyter.

Kamp, Hans \& Uwe Reyle. 1993. From discourse to logic. Introduction to model-theoretic semantics of natural language, formal logic and discourse representation theory. Dordrecht: Kluwer Academic Publishers.

Kornfeld, Laura Malena. 2014. Lecturas alternativas del futuro. Usos y significados de la perífrasis ir $a+$ infinitivo. Traslaciones 1 (1), 8-29.

Laca, Brenda. 2016. Variación y semántica de los tiempos verbales: el caso del futuro. (Documento de trabalho dosponível em linha em https://hal.archives-ouvertes.fr/hal-01533046/)

Lenci, Alessandro \& Pier Marco Bertinetto. 2000. Aspects, adverbs, and events: habituality vs. perfectivity. Em James Higginbotham, Fabio Pianesi \& Achille C. Varzi (eds.), Speaking of events. 245-287. Nova York / Oxford: Oxford University Press.

Lenci, Alessandro. 1995. The semantic representation of non-quantificational habituals. Em Pier Marco Bertinetto, V. Bianchi, James Higginbotham \& Mario Squartini (eds.), Temporal reference, aspect and actionality, Vol. 1: semantic and syntactic perspectives. 143-158. Torino: Rosenberg \& Sellier.

Lima, José Pinto de. 2001. Sobre a génese e a evolução do futuro com ir em Português. Em Augusto Soares da Silva (org.), Linguagem e cognição. A perspectiva da linguística cognitiva. 119-145. Braga: Associação Portuguesa de Linguística / Universidade Católica Portuguesa - Faculdade de Filosofia de Braga.

Mari, Alda. 2009. Disambiguating the Italian future. Em Proceedings of The Generative Lexicon. 209216. https://dokuwiki.ilc.cnr.it/sites/default/files/GL2009_Proceedings.pdf\#page=223.

Martin, Robert. 1981. Le futur linguistique: temps linéaire ou temps ramifié? (à propos du futur et du conditionnel français). Langages 64, 81-92. https://doi.org/10.3406/lgge.1981.1886

Moens, Marc. 1987. Tense, Aspect and Temporal Reference. Edimburgo: Universidade de Edimburgo. (Dissertação de Doutoramento).

Móia, Telmo. 2017. Aspetos da gramaticalização de ir como verbo auxiliar temporal. Revista da Associação Portuguesa de Linguistica 3, 213-239.

Oliveira, Fátima \& Ana Cristina Macário Lopes. 1995. Tense and aspect in Portuguese. Em Rolf Thieroff (ed.), Tense systems in European languages, Vol II. 95-115. Tübingen: Niemeyer.

Oliveira, Fátima. 1986. O Futuro em Português: alguns aspectos temporais e/ou modais. Em Actas do I Encontro Nacional da Associação Portuguesa de Linguística. 353-374. Lisboa: Associação Portuguesa de Linguística. 
Oliveira, Fátima. 1987. Algumas considerações acerca do Pretérito Imperfeito. Em Actas do 2. ${ }^{\circ}$ Encontro da Associação Portuguesa de Linguística. 78-96. Lisboa: Associação Portuguesa de Linguística.

Oliveira, Fátima. 2013. Tempo verbal. Em Eduardo Paiva Raposo, Maria Fernanda Bacelar do Nascimento, Maria Antónia Coelho da Mota, Luísa Segura \& Amália Mendes (orgs.), Gramática do Português, Vol I, Cap. 15. 509-553. Lisboa: Fundação Calouste Gulbenkian.

Palmer, Frank Robert. 1986. Mood and Modality. Cambridge: Cambridge University Press.

Portner, Paul. 2009. Modality. Oxford: Oxford University Press.

Reichenbach, Hans. 1947. Elements of Symbolic Logic. Londres: MacMillan.

Rocci, Andrea. 2000. L'interprétation épistémique du futur en italien et en français: une analyse procédurale. Cahiers de linguistique française 22, 241-274. https://clf.unige.ch/files/2814/4102/7767/ 09-Rocci_nclf22.pdf

Rojo, Guillermo \& Alejandro Veiga. 1999. El tiempo verbal. Los tiempos simples. Em Ignacio Bosque \& Violeta Demonte (orgs.) Gramática descriptiva de la lengua española. 2867-2934. Madrid: Espasa Calpe.

Rojo, Guillermo. 1974. La temporalidad verbal en español. Verba 1, 68-149.

Sarkar, Anoop. 1998. The conflict between future tense and modality: the case of will in English. University of Pennsylvania Working Papers in Linguistics 5 (2). https://repository.upenn.edu/pwpl/ vol5/iss $2 / 6$

Silva, Ademar. 1997. A Expressão da Futuridade na Lingua Falada. Campinas, São Paulo: Universidade Estadual de Campinas - Instituto de Estudos da Linguagem. (Dissertação de doutoramento).

Smith, Carlota S. 1991. The Parameter of Aspect. Dordrecht: Kluwer Academic Publishers.

Soto, Guillermo. 2008. Sobre el llamado futuro de probabilidad. Algunas condiciones del valor modal de -ré. Boletín de Filología 43 (1), 193-206.

Squartini, Mario \& Pier Marco Bertinetto. 2000. The simple and compound past in Romance languages. Em Östen Dahl (ed.), Tense and Aspect in the Languages of Europe. Empirical Approaches to Language Typology. 403-440. Berlim: Mouton de Gruyter. https://doi.org/10.1515/9783110197099.3.403

Stage, Lilian. 2002. Les modalités épistémique et déontique dans les énoncés au futur (simple et composé). Revue Romane 37 (1), 44-66. https://tidsskrift.dk/revue_romane/article/view/31059

Swart, Henriètte de. 1998. Aspect shift and coercion. Natural Language \& Linguistic Theory 16 (2), 347-385. https://doi.org/10.1023/A:1005916004600

Vendler, Zeno. 1967. Linguistics in Philosophy. Nova York: Cornell University Press. https://doi. org/10.7591/9781501743726

Vet, Co. 1994. Future tense and discourse representation. Em Co Vet \& Carl Vetters (eds.), Tense and Aspects in Discourse. 49-76. Berlim / Nova York: Mouton de Gruyter. https://doi. org/10.1515/9783110902617 